\title{
Integrating forest-pasture: Spatial analysis and delineation of zones of litter production and nutrient return
}

\section{Integração floresta-pasto: análise espacial e delineamento de zonas de produção de serapilheira e retorno de nutrientes}

\author{
Sabino Pereira da Silva Neto ${ }^{1 *}$; Antonio Clementino dos Santos ${ }^{2}$; \\ Raimundo Laerton de Lima Leite ${ }^{3}$; José Expedito Cavalcante da Silva²; \\ Durval Nolasco Neves Neto ${ }^{4}$; Marcos Odilon Dias Rodrigues; \\ Nayara Martins Alencar ${ }^{4}$
}

\begin{abstract}
This study aimed to quantify, describe, and identify plant litter production and nutrient accumulation zones in different forest-pasture integration (FPI) systems and forest strata of the Cerrado-Amazon transition on typical orthic Quartzarenic Neosol using spatial analysis, principal component analysis, and non-hierarchical fuzzy k-mean clustering logic techniques. The evaluations were performed at two FPI systems comprising a combination of Brachiaria brizantha cv. Marandu and thinned native vegetation with 50 and $75 \%$ (FPI-I and FPI-II, respectively) shade in an original thinned forest (NFI) and in an original intact forest (NF-II) with 80 and $95 \%$ shade, respectively. An area of $4,000 \mathrm{~m}^{2}$ $(40 \times 100 \mathrm{~m})$ that contained 32 sampling points arranged in a $4 \times 25 \mathrm{~m}$ grid was demarcated for each treatment. Plant litter was collected using 32 collectors installed at equidistant points. Twelve nylon bags were placed on the soil surface at each point to evaluate the plant litter decomposition, totaling 384 bags per treatment. It was possible to quantify, describe, and define plant litter production and nutrient accumulation zones in different FPI systems and forest strata of the Cerrado-Amazon transition on orthic Quartzarenic Neosol using geostatistical analysis, principal components, and non-hierarchical fuzzy k-mean clustering logic procedures.
\end{abstract}

Key words: Precision agriculture, principal component analysis, geostatistics, ordinary kriging, fuzzy k-mean logic, soil management, special variability

\section{Resumo}

O objetivo foi quantificar, descrever e identificar zonas de produção de serapilheira e acúmulo de nutrientes em diferentes sistemas de integração floresta-pasto e estratos de floresta de transição CerradoAmazônia sobre Neossolo Quartzarênico Órtico típico, utilizando técnicas de análise espacial, de análise de componentes principais e da lógica de agrupamento não hierárquica de fuzzy k-médias. As avaliações foram realizadas em dois sistemas de integração floresta-pasto originários da associação de Brachiaria brizantha cv. Marandu e vegetação nativa raleada com $50 \%$ e $75 \%$ (IFP-I e IFP-II, respectivamente) de sombreamento numa floresta original raleado (FN-I) e em floresta original intacta (FN-II) com 80\%

\footnotetext{
${ }^{1}$ Prof., Universidade Federal de Tocantins, IFTO, Gurupi, TO, Brasil. E-mail: sabino.pereira@ifto.edu.br

2 Profs., UFT, Araguaína, TO, Brasil. E-mail: clementino@mail.uft.edu.br, jecs@uft.edu.br

3 Prof., IFTO, Araguatins, TO, Brasil. E-mail: laerton.leite@ifto.edu.br

${ }^{4}$ Discentes do Curso de Doutorado, Ciência Animal Tropical, UFT, Araguaína, TO, Brasil. E-mail: durval.nolasco@gmail.com; marcosodilon22@gmail.com; nayara_m1@hotmail.com

* Author for correspondence
} 
e $95 \%$ de sombreamento, respectivamente. Para cada tratamento foi demarcada uma área de $4.000 \mathrm{~m}^{2}$ $(40 \times 100 \mathrm{~m})$ que continham 32 pontos de coleta dispostos em malha de $4 \times 25 \mathrm{~m}$. A serapilheira foi coletada por meio da instalação nos pontos equidistantes de 32 coletores. Para avaliar a decomposição da serapilheira foram distribuídas 12 sacolas de náilon na superfície do solo em cada ponto, totalizando 384 sacolas por tratamento. É demonstrado que é possível quantificar, descrever e definir zonas de produção de serapilheira e acúmulo de nutrientes em diferentes sistemas de integração floresta-pasto e estratos de floresta de transição Cerrado-Amazônia sobre Neossolo Quartzarênico Órtico, utilizando os procedimentos de análise geoestatística, de componentes principais e da lógica de agrupamento não hierárquica de fuzzy k-médias.

Palavras-chave: Agricultura de precisão, análise componentes principais, geoestatística, krigagem ordinária, lógica fuzzy k-médias, manejo do solo, variabilidade especial

\section{Introduction}

Silvopastoral systems (SPSs) are characterized by the incorporation of trees and shrubs into livestock production practices in any temporal or spatial arrangement. SPSs can be defined as systems that simultaneously or sequentially combine forest plant production with animals and pastures within the same area to obtain products or services from these three components (PACIULLO et al., 2008). Thus, these SPSs comprise important tools for sustainable development because they combine production with natural resource conservation (water and soil) and meet the farmers' different needs, such as food, wood, firewood, forage, medicinal plants, and fibers (DIAS-FILHO, FERREIRA, 2007).

SPSs aim to make Brazilian livestock production competitive and environmentally adjusted by establishing different plant strata, which are considered basic and key structural elements for system stability because of the effects that they exert on the nutrient cycling process and solar energy use (PACIULLO et al., 2008). The use of SPSs has beneficial effects, such as incorporating nutrients and increasing microbial activity in the soil (XAVIER et al., 2003; NEVES et al., 2009). According to Menezes et al. (2002), nutrients are incorporated through the absorption of these elements by the trees' roots, deeper soil layers, and subsequent deposition on the soil surface from the decomposition of leaves, fruit, and roots.

Nutrient incorporation depends on the plant litter decomposition rate and the quantity of biomass deposited onto the soil (LUIZÃO, 2007). Thus, variation in plant litter production will have distinct responses regarding nutrient input into the system. Plant litter production varies according to tree spatial arrangement and climatic conditions, and it depends on the biome in which the plants are found. Higher quantities of plant litter are deposited at forest sites compared to the savannah within the Amazon-Cerrado transition regions, particularly during the dry season (SILVA et al., 2007).

Despite deposited plant litter exhibiting the potential for mineral nutrient return (REIS et al., 2009; SILVA et al., 2009), this can only occur at the sites affected by tree canopy. This increases the spatial variability of plant litter production and nutrient return. Additionally, higher shade levels within these accumulation zones may interfere in grass development and production established under the tree canopy (PACIULLO et al., 2011), thus preventing use efficiency and/or the intake of these nutrients.

The Amazon rainforest has high plant species diversity, resulting in plants that return nutrients to the soil at different time durations and quantities (SILVA et al., 2009). This diversity further hinders understanding and determining the homogeneous zones within SPS sites. Thus, the non-hierarchical clustering technique known as fuzzy k-mean, which was proposed by Minasny and McBratney (2002), aims to identify natural groupings that occur in the data. Molin and Castro (2008) used this technique to determine homogeneous areas, and it may become 
a feasible alternative to understanding the zones affecting trees in forest-pasture integration (FPI) systems.

This study aimed to quantify, describe, and identify plant litter production and nutrient accumulation zones in different FPI systems and forest strata of the Cerrado-Amazon transition on typical orthic Quartzarenic Neosol using spatial analysis, principal component analysis, and non-hierarchical fuzzy k-mean clustering logic techniques.

\section{Materials and Methods}

The study sites were located at the farm of the School of Veterinary Medicine and Animal Science (Escola de Medicina Veterinária e Zootecnia), Araguaína campus of the Federal University of Tocantins (Universidade Federal do Tocantins). The region is climate type Aw (hot wet) according to the Köppen classification with a dry season lasting from April to October. The mean annual rainfall is 1,800 $\mathrm{mm}$, and the mean temperature is $28^{\circ} \mathrm{C}$. The soil of the site is classified as typical orthic Quartzarenic Neosol according to the Brazilian Soil Classification System (Sistema Brasileiro de Classificação de Solos - SiBCS) (EMBRAPA, 2006).

The evaluations were performed in two FPI systems comprising a combination of Brachiaria brizantha $\mathrm{cv}$. Marandu and thinned native vegetation with 50 and 75\% (FPI-I and FPI-II, respectively) shade in an original thinned forest (NF-I) and an original intact forest (NF-II) with 80 and $95 \%$ shade, respectively. An area of 4,000 $\mathrm{m}^{2}(40 \mathrm{x} 100$ $\mathrm{m})$ that contained 32 sampling points arranged in a $4 \times 25 \mathrm{~m}$ grid was demarcated for each treatment.

The shade level was adjusted at each site studied based on the illuminance level (lux) using an Instrutherm LD 200 model light meter at 32 equidistant points of each treatment during three periods of the year. The readings were simultaneously obtained inside the forest and in full sun between 8:00 AM and 10:00 AM. The following was estimated based on this information: shade $=100-[$ (reading inside the forest/reading in full sun)*100], expressed in $\%$.

Before planting Marandu grass in December 2009, 1,500 kg ha-1 of dolomitic limestone was applied. After application, the limestone was incorporated into the soil using two diskings at the Marandu grass monoculture site, and it was manually incorporated at the FPI-I and FPI-II sites. The Marandu cultivar of Brachiaria brizantha was sowed in February 2010 with a sowing rate of $6 \mathrm{~kg}$ of seeds ha- ${ }^{-1}$ A total of $70 \mathrm{~kg} \mathrm{ha}^{-1}$ of $\mathrm{P}_{2} \mathrm{O}_{5}$ and $\mathrm{K}_{2} \mathrm{O}$ was applied in single superphosphate and potassium chloride forms, respectively. At the NF-I site, we initially attempted to establish Marandu grass in the pasture. However, high shade $(80 \%)$ reduced light incidence in the understory, which prevented grass development.

Collectors (surface area of $0.25 \mathrm{~m}^{2}$, height of 10 $\mathrm{cm}$ from the edge, with a nylon screen bottom with 1-mm mesh, and suspended $50 \mathrm{~cm}$ from the soil) were installed to quantify the plant litter production. These collectors were installed individually and were systematically distributed at 32 equidistant points in each treatment. The material deposited in the collectors was collected monthly to estimate the quantity of plant litter that was produced, totaling 12 collections throughout the experimental year. The deposited plant litter was weighed and placed in duly labeled paper bags that were placed in a forced-circulation oven for 72 hours at $65^{\circ} \mathrm{C}$. The biomass that was returned to the soil at the sites investigated monthly and annually was estimated based on the mean quantity of plant litter found in the collectors.

The plant litter existing on the soil, at varying degrees of decomposition, was collected during the experiment to evaluate plant litter decomposition. This material was dried in an oven at $65^{\circ} \mathrm{C}$ until reaching a constant weight. Fifteen grams of dried plant litter was weighed and placed into nylon bags 
(20 cm x $20 \mathrm{~cm}$ ) made of 1-mm mesh nylon screen. Twelve nylon bags were placed on the soil surface at the points where the eight collectors of each experimental unit were located, totaling 384 bags per treatment. One bag surrounding each collector was randomly removed monthly throughout a oneyear period. Once collected, the nylon bags were brought to the laboratory where the soil particles were removed and then dried in an oven at $65^{\circ}$. The residual mass was determined on an analytical balance with $0.01 \mathrm{~g}$ precision; this value was used to estimate the decomposition speed ( $\mathrm{g} / \mathrm{month}$ ) of this material compared to the initial weight (15 g). The percentage of remaining material was calculated using the following equation:

$$
\% \text { Remanescente }=\frac{\text { Massa }_{\text {final }}}{\text { Massa }_{\text {inicial }}} \times 100
$$

A first-order exponential equation was used to calculate the decomposition rate $\left(\mathrm{k}\left(\mathrm{g} \mathrm{g}^{-1}\right.\right.$ day $\left.\left.^{-1}\right)\right)$ : $\mathrm{C}=\mathrm{C}_{0} \mathrm{e}^{-\mathrm{kt}}$ in which: $\mathrm{C}$ is the final mass of the samples $\left(\mathrm{t}_{365}\right) ; \mathrm{C}_{0}$ is the initial mass $(15 \mathrm{~g})$; $\mathrm{t}$ is the elapsed experimentation time (365 days); and $\mathrm{k}$ is the decomposition constant.

The following were determined in the deposited plant litter during each trimester and placed into the nylon bags with the samples from the onset and end of the experiment: nitrogen levels $(\mathrm{N})$ by the Kjeldahl method, phosphorus levels (P) by photocolorimetry, potassium levels $(\mathrm{K})$ by flame photometry, and calcium (Ca) and magnesium levels $(\mathrm{Mg})$ by titration (EMBRAPA, 2005).

Initially, the data collected from the sites studied were subjected to exploratory analyses to test whether the data occurred randomly or aggregated. The mean, median, minimum, maximum, coefficients of asymmetry, kurtosis, and variation were calculated, and the distribution type was identified. The Kolmogorov-Smirnov test at $5 \%$ significance was used to test the hypothesis of normality. The limits of the coefficient of variation
(CV) were classified as low $(\mathrm{CV}<12 \%)$, medium $(12<\mathrm{CV}<60 \%)$, and high $(\mathrm{CV}>60 \%)$ as proposed by Warrick and Nielsen (1980) to classify variability in the data.

To statistically evaluate the sites, multiple comparisons of the mean ranks were performed by the Kruskal-Wallis non-parametric test at a $5 \%$ significance level for the datasets that were not normally distributed and a Tukey test at 5\% significance for those that were normally distributed. The Action R program (version 2.3) was used to compare the treatments using the means found for each variable.

The pattern of spatial dependence was characterized by geostatistical analysis, calculating the semivariance using the equation proposed by Matheron (1963). The experimental semivariance values were determined using the $\mathrm{GS}^{+}$program (ROBERTSON, 2008).

Initially, the visual fit of the model selected for the experimental semivariogram cloud points was performed. In thisstudy, the following semivariogram models were tested: spherical, exponential and Gaussian. Fitting the semivariograms allowed for defining the values of the nugget effect $\left(\mathrm{C}_{0}\right)$, range effect (A), and level effect (C+ $\mathrm{C}_{0}$ ) (VIEIRA, 2000).

The model fit of the semivariograms was selected based on minimizing the sum of the squared residuals (SSR) and the highest multiple coefficient of determination $\left(\mathrm{R}^{2}\right)$. In addition, the performance of each model was evaluated by Akaike's criterion (AIC) using the Vesper 1.6 program (MINASNY et al., 2006).

The proportion given by the equation proposed by Robertson (2008) was used to analyze the degree of spatial dependence (DSD), which allows for classifying DSD as weak spatial dependence (DSD $\leq 25 \%$ ), moderate spatial dependence $(25 \%<\mathrm{DSD} \leq 75 \%)$, and strong spatial dependence (DSD $>75 \%$ ). 
The values were interpolated by the ordinary kriging method to define the spatial pattern of the variables at the sites, which allowed for constructing contour maps (VIEIRA, 2000). Spatial variability maps were constructed using the Surfer 8.0 program (GOLDEN SOFTWARE, 2002).

Principal component analysis (PCA) was performed based on the existing correlation matrix between the components and the actual attributes to identify new variables that explain the largest portion of the variability, thus generating new values for each variable obtained via the ordinary kriging process, corresponding to the principal components. The principal components with eigenvalues higher than one or with a variance greater than or equal to $70 \%$ were selected as recommended by Mardia et al. (1979). Through these techniques it was possible to identify which variables best represent the sites' characteristics.

Based on the principal components selected, the obtained new variables were grouped by transforming the variables using the non-hierarchical fuzzy k-mean method.

The zones were defined using the FuzMe program, version 3.0 (MINASNY, MCBRATNEY, 2002). Initially, the minimum (2) and maximum number (5) of classes, maximum number of interactions (300), fuzzy exponent (1.2), criterion for ending the analysis (0.0001), and distance type (Euclidean) were defined for use among the observations and the centroid of each class.

The fuzziness performance index (FPI) and modified partition entropy (MPE) were used to determine the optimal number of units. The optimal number of class groupings was thus defined as when these two indices approximately reached the minimum.
Analysis of variance (ANOVA) was performed for the variables collected among the different zones generated by the grouping to test whether differences existed between the means. The honest significant difference Tukey test for different sized samples was used to compare the classes.

\section{Results and Discussion}

Plant litter production (Figure 1) from September 2010 to August 2011 occurred continuously throughout the year with considerable variation among the months. Higherdeposition was recorded at the sites studied during months of lower rainfall with predominantly higher temperatures, thus showing seasonal characteristics. This seasonality may be the vegetation's response to water stress caused by the dry season considering that clearing away the leaves may reduce the breathable surface, thus avoiding or tolerating drought (CIANCIARUSO et al., 2006). According to (LUIZÃO, SCHUBART, 1987), plant litter deposition in the rainforest is seasonal, with a higher decline in litter during the dry season.

According to Rodrigues and Leitão Filho (2004), plant litter production within a same climatic zone results in complex interactions between local factors such as soil fertility, water availability in the soil, and the degree of vegetation disturbance. Therefore, it is noteworthy that human intervention at the FPI-I, FPI-II, and NF-I sites such as forest thinning, soil correction and fertilization were unable to alter the seasonal patterns of plant litter deposition.

The seasonality in biomass deposition by trees was similar to that found by Silva et al. (2007), Sanches et al. (2008, 2009), and Silva et al. (2009) in a forest of the Amazon-Cerrado transition on orthic Quartzarenic Neosol. 
Figure 1. Monthly variation in plant litter deposition in forest-pasture integration systems of Marandu grass with 50 (FPI-I) and 70\% (FPI-II) shade in a thinned forest with $80 \%$ shade (NF-I) and an intact native forest (NF-II).

\section{IFP-I}

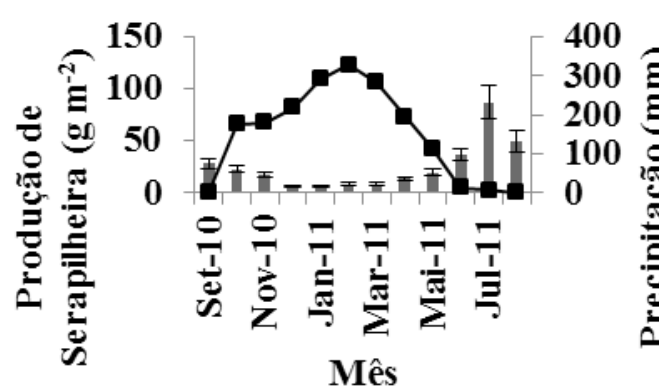

FN-I

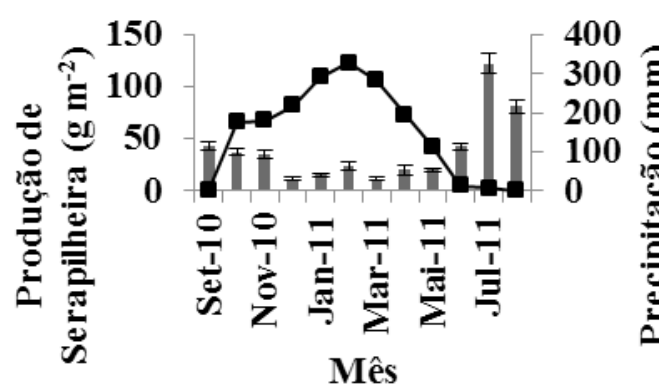

IFP-II

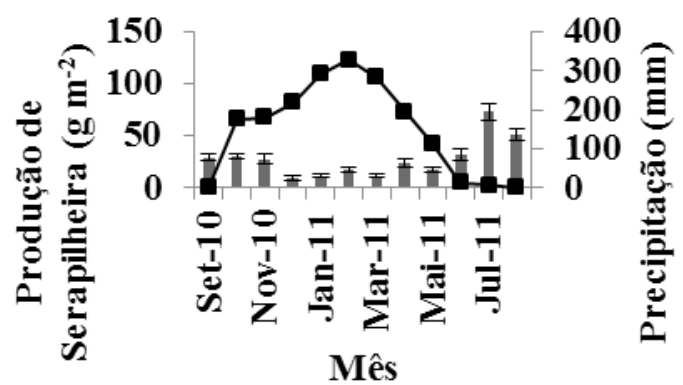

FN-II

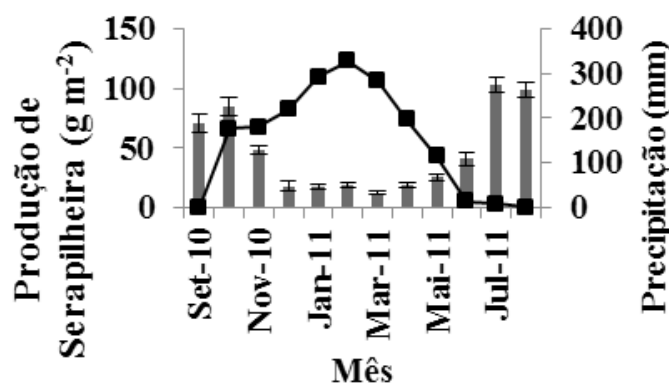

The mean plant litter production was 25.33 , 28.00, 38.73, and $46.16 \mathrm{~g} \mathrm{~m}^{-2}$ month $^{-1}$ among the FPI-I, FPI-II, NF-I, and NF-II sites, respectively. This situation was expected considering that the forest was thinned at the FPI-I and FPI-II sites to reduce shade to allow the Marandu grass to grow, which ended up reducing the monthly litter input by 43.91 and $39.36 \%$ compared to an intact forest. It is noteworthy that when comparing the monthly mean plant litter production among the sites, only the NF-I and NF-II sites did not significantly differ (Kruskal-Wallis, $\mathrm{p}<0.0001$ ) (Figure 1). Thus, in response to the monthly deposition and thinning performed in the forest to reduce shade, annual plant litter production was lower at the FPI-I and FPI-II sites than at the NF-I and NF-II sites (Table 1). According to Vitousek and Sanford (1986), plant litter production in Brazilian tropical forests on low- fertility soils ranges from 640 to $990 \mathrm{~g} \mathrm{~m}^{-2}$ year'-

Annual mineral nutrient return via deposited plant litter decreased by 46.91 and $38.80 \%$ for $\mathrm{N}$ and by 37.97 and $29.11 \%$ for P at the FPI-I and FPIII sites, respectively (Table 1). These sites did not significantly differ regarding the return of these two nutrients. It is noteworthy that the greater thinning at the FPI-I site to ensure less shade was unable to reduce the annual $\mathrm{N}$ and $\mathrm{P}$ inputs compared to FPIII. This nutrient return is important for maintaining the productive system because the soil's chemical properties are unfavorable for grass development and production. Additionally, FPI-I may have competitive advantages compared to FPI-II from the production of the Marandu grass because more shade can reduce grass production (SOUSA et al., 2007). 
Table 1. Descriptive statistics of annual plant litter production, mineral nutrient return, and remaining biomass in forest-pasture integration systems of Marandu grass with 50 (FPI-I) and 70\% (FPI-II) shade in a thinned forest with $80 \%$ shade (NF-I) and an intact native forest (NF-II).

\begin{tabular}{|c|c|c|c|c|c|c|c|c|}
\hline \multirow{2}{*}{ Site } & \multirow{2}{*}{ Mean } & \multirow{2}{*}{$\operatorname{Med}^{1}$} & \multirow{2}{*}{$\operatorname{Min}^{2}$} & \multirow{2}{*}{$\operatorname{Max}^{3}$} & \multicolumn{3}{|c|}{ Coefficient } & \multirow{2}{*}{$\mathrm{KS}^{4} \mathrm{p}$-value } \\
\hline & & & & & Variation & Asymmetry & Kurtosis & \\
\hline \multicolumn{9}{|c|}{ Total plant litter } \\
\hline FPI-I & $303.93(43.69) b$ & 208.36 & 23.36 & 916.92 & 81.31 & 0.99 & -0.03 & $0.01^{*}$ \\
\hline FPI-II & $336.00(28.30) \mathrm{b}$ & 344.64 & 47.40 & 811.04 & 47.64 & 0.39 & 1.65 & $0.20^{*}$ \\
\hline NF-I & $464.76(20.69)$ a & 456.96 & 272.24 & 748.52 & 25.19 & 0.43 & -0.50 & $0.26^{*}$ \\
\hline NF-II & $553.96(29.46)$ a & 541.20 & 229.08 & 892.56 & 30.08 & 0.36 & -0.38 & $0.45^{*}$ \\
\hline \multicolumn{9}{|c|}{ Total N } \\
\hline FPI-I & $3.01(0.44) b$ & 2.04 & 0.22 & 9.05 & 82.31 & 0.94 & -0.20 & $0.01^{* *}$ \\
\hline FPI-II & $3.47(0.30) \mathrm{b}$ & 3.32 & 0.43 & 7.90 & 49.90 & 0.35 & 0.56 & $0.01^{* *}$ \\
\hline NF-I & $4.67(0.21) \mathrm{a}$ & 4.54 & 2.76 & 7.93 & 25.49 & 0.71 & 0.38 & $0.41^{*}$ \\
\hline NF-II & $5.67(0.33) \mathrm{a}$ & 5.71 & 2.22 & 9.96 & 32.72 & 0.57 & 0.02 & $0.15^{*}$ \\
\hline \multicolumn{9}{|c|}{ Total P } \\
\hline FPI-I & $0.49(0.07) \mathrm{b}$ & 0.33 & 0.04 & 1.54 & 84.36 & 1.10 & 0.28 & $0.03^{* *}$ \\
\hline FPI-II & $0.56(0.05) b$ & 0.59 & 0.06 & 1.57 & 53.55 & 0.86 & 2.86 & $0.23^{*}$ \\
\hline NF-I & $0.75(0.03) \mathrm{a}$ & 0.75 & 0.44 & 1.25 & 24.29 & 0.96 & 1.41 & $0.32^{*}$ \\
\hline NF-II & $0.79(0.04) \mathrm{a}$ & 0.76 & 0.32 & 1.21 & 28.59 & 0.10 & -0.62 & $0.76^{*}$ \\
\hline \multicolumn{9}{|c|}{ Total K } \\
\hline FPI-I & $0.54(0.08)$ a & 0.39 & 0.044 & 1.66 & 82.54 & 1.15 & 0.47 & $0.004^{* *}$ \\
\hline FPI-II & $0.51(0.05) \mathrm{a}$ & 0.51 & 0.060 & 1.69 & 60.66 & 1.58 & 5.78 & $0.09^{*}$ \\
\hline NF-I & $0.57(0.03) \mathrm{a}$ & 0.52 & 0.34 & 1.04 & 28.47 & 1.09 & 1.23 & $0.11^{*}$ \\
\hline NF-II & $0.49(0.03) \mathrm{a}$ & 0.47 & 0.24 & 0.84 & 35.35 & 0.41 & -0.83 & $0.19^{*}$ \\
\hline \multicolumn{9}{|c|}{ Total Ca } \\
\hline FPI-I & $0.43(0.07) b$ & 0.28 & 0.04 & 1.42 & 89.16 & 1.20 & 0.54 & $0.007^{* *}$ \\
\hline FPI-II & $0.40(0.04) \mathrm{ab}$ & 0.38 & 0.04 & 1.17 & 55.67 & 1.08 & 3.62 & $0.32^{*}$ \\
\hline NF-I & $0.49(0.02) \mathrm{a}$ & 0.46 & 0.32 & 0.82 & 23.23 & 0.83 & 0.61 & $0.28^{*}$ \\
\hline NF-II & $0.41(0.02) \mathrm{ab}$ & 0.39 & 0.20 & 0.67 & 30.14 & 0.48 & -0.68 & $0.48^{*}$ \\
\hline \multicolumn{9}{|c|}{ Total Mg } \\
\hline FPI-I & $0.32(0.05) \mathrm{d}$ & 0.20 & 0.030 & 1.14 & 98.77 & 1.37 & 0.93 & $0.003^{* *}$ \\
\hline FPI-II & $0.32(0.03) \mathrm{cd}$ & 0.30 & 0.032 & 0.91 & 56.29 & 0.92 & 2.56 & $0.46^{*}$ \\
\hline NF-I & $0.37(0.03) b c$ & 0.37 & 0.049 & 0.91 & 40.65 & 1.18 & 4.77 & $0.21^{*}$ \\
\hline NF-II & $0.50(0.03) \mathrm{ab}$ & 0.44 & 0.19 & 1.05 & 40.75 & 0.93 & 0.45 & $0.23^{*}$ \\
\hline \multicolumn{9}{|c|}{ Remaining biomass $(\%) \dagger$} \\
\hline FPI-I & $57.58(1.54) \mathrm{a}$ & 58.73 & 38.27 & 71.67 & 14.90 & -0.23 & -0.44 & $0.92^{*}$ \\
\hline FPI-II & $55.83(1.27) \mathrm{a}$ & 56.73 & 38.60 & 70.53 & 12.80 & -0.13 & 0.54 & $0.23^{*}$ \\
\hline NF-I & $57.08(1.62) \mathrm{a}$ & 56.93 & 46.53 & 86.40 & 15.80 & 1.24 & 2.34 & $0.19^{*}$ \\
\hline NF-II & $50.20(1.03) \mathrm{a}$ & 53.73 & 41.00 & 67.46 & 11.00 & 0.15 & 0.68 & $0.34^{*}$ \\
\hline \multicolumn{9}{|c|}{ Shade $(\%)$} \\
\hline FPI-I & $57.90(5.09) \mathrm{c}$ & 65.02 & 1.93 & 92.57 & 49.80 & -0.53 & -0.97 & $0.21^{*}$ \\
\hline FPI-II & $71.81(4.54) b$ & 83.49 & 2.15 & 95.17 & 35.78 & -1.41 & 1.16 & $9 \times 10^{-5 * *}$ \\
\hline NF-I & $80.53(3.13) b$ & 87.58 & 20.09 & 96.72 & 21.98 & -1.61 & 2.88 & $5 \times 10^{-5 * *}$ \\
\hline NF-II & $96.73(0.23) \mathrm{a}$ & 96.88 & 94.09 & 98.91 & 1.38 & -0.40 & -0.73 & $0.09^{*}$ \\
\hline
\end{tabular}

Means followed by the same letter in the column do not differ among themselves (Kruskal-Wallis and ( $\dagger$ ) Tukey at $5 \%$ ). The values in parentheses refer to the standard error of the mean. ${ }^{(1)}$ Med.: median; ${ }^{(2)}$ Min.: minimum; ${ }^{(3)}$ Max.: maximum; ${ }^{(43)} \mathrm{KS}$ : KolmogorovSmirnov normality test; ${ }^{(*)}$ : significant at $5 \%{ }^{\left({ }^{* *}\right)}$ : non-significant. 
Reis et al. (2009) found that litter from the trees (leaves, fruit, and branches) of an FPI within the Cerrado region returned 7.8, 0.3, 3.9, and $2.7 \mathrm{~g} \mathrm{~m}^{-2}$ year $^{-1}$ of $\mathrm{N}, \mathrm{P}, \mathrm{K}$, and $\mathrm{Ca}$, respectively, to the soil. Xavier et al. (2011) found $\mathrm{N}$ deposition of $2.28 \mathrm{~g} \mathrm{~m}^{-2}$ year ${ }^{-1}$ in an FPI of Urochloa decumbens cv. Basilisk within a region of the Atlantic Forest.

The $\mathrm{Ca}$ levels at the FPI-I and FPI-II sites remained equal to those in the intact forest whereas the $\mathrm{Mg}$ levels decreased by $36 \%$ compared to NFII. The $\mathrm{K}$ return remained equal among the sites studied, regardless of the shade level (Table 1). According to Luizão (2007), K is highly watersoluble and is thus very susceptible to leaching and usually has an extremely rapid release rate; litter can lose up to $80 \%$ of its $\mathrm{K}$ content within the first 30 days of decomposition. Thus, a lower plant litter decomposition rate favors the gradual release of the mineral $\mathrm{K}$, which can thus to be used by grasses grown in the understory.

Plant litter decomposition, which is measured by determining the loss of dry mass inside the nylon bags, remained equal among the sites studied. The mean weight loss of the material ranged from 42.42 to $49.80 \%$ within the 12 -month period (Table 1). Sanches et al. (2009) found a $51.30 \%$ loss of material within a 220-day period in a forest of the Amazon-Cerrado transition. Silva et al. (2009) found $52.10 \%$ decomposition after 12 months of the material's exposure within the same transition region. However, Freire et al. (2010) found only $30 \%$ decomposition of the material incubated for 256 days under a "sabiá" (Mimosa caesalpiniifolia) understory implemented within the Northern Forest Zone of Recife (Zona da Mata Setentrional de Recife). According to Luizão (2007), litter decomposition significantly depends on the action of soil organisms (microorganisms, mesofauna, and macrofauna) and rainfall patterns because moisture is favorable for biological action.

The decomposition rate exhibited a satisfactory fit to the exponential model based on the material's exposure duration and the percentage of material remaining after incubation at the study sites (Table 2). An analysis considering variation in the decomposition rate of each site shows that there was no significant difference among the four sites (Friedman, $\mathrm{p}>0.05$ ). The incubated plant litter decomposition rates varied between -0.0018 and $-0.0021 \mathrm{~g} \mathrm{~g}^{-1}$ per day. In incubating leaves from four species of the Amazon-Cerrado transition zone during the dry and rainy periods, Silva et al. (2009) found decomposition rates ranging between -0.0013 and $-0.012 \mathrm{~g} \mathrm{~g}^{-1}$ per day. Sanches et al. (2009) found decomposition rates of -0.003 and $-0.0017 \mathrm{~g} \mathrm{~g}^{-1}$ per day during the dry-wet season and wet-dry season, respectively. Freire et al. (2010) obtained a rate of -0.00073 and $-0.00103 \mathrm{~g} \mathrm{~g}^{-1}$ per day for leaves and branches, respectively.

Table 2. Exponential equations fitted to the values of the samples after 12 months of decomposition, plant litter decomposition constant $(\mathrm{k})$, and time necessary to decompose $50 \%$ of the biomass $\left(\mathrm{t}_{0.5}\right)$ in Marandu grass silvopastoral systems with 50 (FPI-I) and 70\% (FPI-II) shade in a thinned forest with $80 \%$ shade (NF-I) and an intact native forest (NF-II).

\begin{tabular}{lccccc}
\hline \multicolumn{1}{c}{ Site } & Equation & ${\mathrm{k}\left(\mathrm{g} \mathrm{g}^{-1} \text { day }^{-1}\right)}$ & $\mathrm{t}_{0.5}$ (days) & $\mathrm{t}_{0.5}$ (months) & $\mathrm{t}_{0.5}$ (years) \\
\hline FPI-I & $\mathrm{C}=15.53 \mathrm{e}^{-0.0018 \mathrm{t}}$ & -0.0018 & 385.08 & 12.66 & 1.05 \\
FPI-II & $\mathrm{C}=16.25 \mathrm{e}^{-0.0021 \mathrm{t}}$ & -0.0021 & 330.07 & 10.85 & 0.90 \\
NF-I & $\mathrm{C}=15.56 \mathrm{e}^{-0.0018 \mathrm{t}}$ & -0.0018 & 385.08 & 12.66 & 1.05 \\
NF-II & $\mathrm{C}=15.33 \mathrm{e}^{-0.0022 \mathrm{t}}$ & -0.0022 & 315.07 & 10.36 & 0.86 \\
\hline
\end{tabular}


Considering these results, it is noteworthy that despite removing trees to reduce and adjust the shade levels at the FPI sites, the decomposition rates remained equal to those at the forest sites (Table 2). This decomposition may ensure the input of mineral nutrients from the biomass deposited onto the soil. It is noteworthy that there was no presence of grazing animals at the FPI sites, which can alter the plant litter decomposition rate patterns because trampling can help break up difficult-to-degrade substances.

The results of the Kolmogorov-Smirnov normality test (Table 1) indicate the absence of normality in the data for most of the variables at the FPI-I site. Regarding annual plant litter and biomass production remaining in the decomposition bags, all of the sites exhibited normal distribution in the data (Table 1). Vieira et al. (2010) found that the leaf nutrient levels of the soybeans under no-tillage exhibited a normal distribution. Geostatistical analysis does not require the data to exhibit a normal distribution, but identifying the occurrence of very asymmetrical distributions is interesting (ISAAKS, SRIVASTAVA, 1989).

According to the classification criteria of the coefficient of variation (CV) proposed by Warrick and Nielsen (1980), annually deposited plant litter and its return of mineral nutrients to the soil exhibited high variability $(\mathrm{CV}>60 \%)$ at the FPI-I site and medium variability at the other locations $(12<\mathrm{CV}<60 \%)$. The remaining biomass in decomposition bags at all of the sites exhibited medium variability $(12<\mathrm{CV}<60 \%)$. Shade level exhibited low variability $(\mathrm{CV}>12 \%)$ at the NF-II site but medium variability at the other locations $(12<\mathrm{CV}<60 \%)$ (Table 1$)$.

The high variability in the data at FPI-I indicates that although obtaining plant litter production values and mineral nutrient input at a quantity that ensures grass production, residues may have been deposited at specific sites, i.e., within certain accumulation zones. Thus, these zones may only slightly contribute to the total grass production because they occur where the trees' canopy is projected, which has lower luminosity. According to Paciullo et al. (2011), the arboreal component alters most of the pasture's characteristics in an agrosilvopastoral system because of its remoteness from tree hedgerows. In the study by Oliveira et al. (2007), who evaluated Brachiaria brizantha cv. Marandu yield under different structural arrangements of SPSs with eucalypti (in simple and double rows) that were implemented in the Cerrado of Northwestern Minas Gerais state, Brazil, there was always higher available forage in-between the rows than in the planting rows, regardless of the eucalyptus planting arrangement.

A coefficient of variation lower than $35 \%$ indicates that the data series is homogeneous and the mean is significant, which can thus be representative of the site where it was obtained. Datasets with CV values higher than $35 \%$ are heterogeneous and the mean is slightly significant, but if they exhibit a CV higher than $65 \%$, the series is very heterogeneous and the mean is not significant at all (NOGUEIRA, 2007). Thus, using mean values does not adequately represent the variables at the sites studied, which may result in errors in distinguishing the sites. Therefore, information regarding the spatial variability of the variables should be incorporated through studies of spatial autocorrelation (KRAVCHENKO et al., 2006), which would help reduce the standard error of the mean estimates (CERRI et al., 2004; VIEIRA et al., 2010).

The results of the geostatistical analysis indicate that all of the variables analyzed exhibited spatial dependence defined by omnidirectional semivariograms fitted to the spherical, exponential, and/or Gaussian theoretical models (Table 3). Most of the variables were fit to the spherical and exponential models. Worsham et al. (2010) also found that semivariograms fit to these two models when the carbon and $\mathrm{N}$ levels in the plant litter were studied under different forest cover. Some studies show that the levels of mineral nutrients in the tissue of the plants usually fit to spherical and exponential 
models (VIEIRA et al., 2010; LEÃO et al., 2010; high determination coefficients $\left(\mathrm{R}^{2}\right)$ that ranged CAVALCANTE et al., 2011; RODRIGUES from 0.92 to 0.99 and low squared residual sums JÚNIOR et al., 2011). The fitted models exhibited (SRSs) (Table 3).

Table 3. Models and estimated parameters of the semi-variograms fitted to the annual plant litter production, mineral nutrient return, remaining biomass after 12 months of decomposition, and shade level values in forest-pasture integration systems of Marandu grass with 50 (FPI-I) and 70\% (FPI-II) shade in a thinned forest with $80 \%$ shade (NFI) and an intact native forest (NF-II).

\begin{tabular}{|c|c|c|c|c|c|c|c|c|c|}
\hline \multirow{2}{*}{ Site } & \multirow{2}{*}{ Model } & \multicolumn{8}{|c|}{ Parameter } \\
\hline & & $\mathrm{C}_{0}{ }^{1}$ & $\mathrm{C}_{1}^{2}$ & $\mathrm{~A}^{3}$ & $\mathrm{DSD}^{4}$ & Class & $\mathrm{R}^{2^{*}}$ & $\mathrm{SSR}^{5}$ & $\mathrm{AIC}^{6}$ \\
\hline \multicolumn{10}{|c|}{ Total plant litter } \\
\hline FPI-I & Exponential & 0.00 & 44337 & 36.71 & 100 & Strong & 0.98 & $7 \times 10^{7}$ & 203.10 \\
\hline FPI-II & Spherical & 0.00 & 14590 & 39.18 & 100 & Strong & 0.96 & $5 \times 10^{5}$ & 190.00 \\
\hline NF-I & Gaussian & 346.60 & 8610 & 20.60 & 96 & Strong & 0.98 & $8 \times 10^{5}$ & 174.80 \\
\hline NF-II & Gaussian & 1342.30 & 115666 & 22.21 & 89 & Strong & 0.99 & $4 \times 10^{5}$ & 157.70 \\
\hline \multicolumn{10}{|c|}{ Total N } \\
\hline FPI-I & Exponential & 0.00 & 4.47 & 36.68 & 100 & Strong & 0.97 & 0.14 & 0.05 \\
\hline FPI-II & Gaussian & 0.10 & 1.80 & 19.33 & 94 & Strong & 0.97 & 0.06 & -10.09 \\
\hline NF-I & Gaussian & 0.08 & 1.08 & 28.75 & 92 & Strong & 0.99 & $3 \times 10^{-3}$ & -57.25 \\
\hline NF-II & Gaussian & 0.15 & 1.65 & 25.38 & 91 & Strong & 0.99 & 0.01 & -39.85 \\
\hline \multicolumn{10}{|c|}{ Total P } \\
\hline FPI-I & Exponential & 0.00 & 0.12 & 39.01 & 100 & Strong & 0.97 & 0.14 & -79.16 \\
\hline FPI-II & Gaussian & 0.001 & 0.05 & 18.39 & 96 & Strong & 0.94 & $1 \times 10^{-4}$ & -76.81 \\
\hline NF-I & Spherical & 0.00 & 0.03 & 83.05 & 100 & Strong & 0.99 & $9 \times 10^{-7}$ & -129.20 \\
\hline NF-II & Spherical & 0.00 & 0.01 & 32.23 & 100 & Strong & 0.94 & $6 \times 10^{-6}$ & -120.00 \\
\hline \multicolumn{10}{|c|}{ Total K } \\
\hline FPI-I & Exponential & 0.00 & 0.14 & 40.09 & 100 & Strong & 0.97 & $1 \times 10^{-4}$ & -75.08 \\
\hline FPI-II & Gaussian & 0.003 & 0.07 & 23.13 & 95 & Strong & 0.98 & $5 \times 10^{-5}$ & -89.10 \\
\hline NF-I & Gaussian & 0.001 & 0.01 & 29.39 & 92 & Strong & 0.99 & $1 \times 10^{-6}$ & -129.20 \\
\hline NF-II & Gaussian & 0.002 & 0.02 & 45.53 & 92 & Strong & 0.99 & $1 \times 10^{-6}$ & -128.00 \\
\hline \multicolumn{10}{|c|}{ Total Ca } \\
\hline FPI-I & Exponential & 0.00 & 0.13 & 55.27 & 100 & Strong & 0.97 & $8 \times 10^{-5}$ & -82.38 \\
\hline FPI-II & Spherical & 0.00 & 0.03 & 45.43 & 100 & Strong & 0.95 & $5 \times 10^{-5}$ & -92.32 \\
\hline NF-I & Spherical & 0.00 & 0.007 & 45.87 & 100 & Strong & 0.98 & $1 \times 10^{-6}$ & -129.40 \\
\hline NF-II & Spherical & 0.00 & 0.008 & 61.92 & 100 & Strong & 0.99 & $1 \times 10^{-7}$ & -160.40 \\
\hline \multicolumn{10}{|c|}{ Total Mg } \\
\hline FPI-I & Exponential & 0.00 & 0.16 & 117.20 & 100 & Strong & 0.97 & $3 \times 10^{-5}$ & -90.73 \\
\hline FPI-II & Gaussian & 0.00 & 0.02 & 21.13 & 96 & Strong & 0.98 & $5 \times 10^{-6}$ & -116.70 \\
\hline NF-I & Gaussian & 0.00 & 0.018 & 33.64 & 97 & Strong & 0.99 & $6 \times 10^{-7}$ & -147.10 \\
\hline NF-II & Gaussian & 0.001 & 0.07 & 47.02 & 97 & Strong & 0.99 & $5 \times 10^{-6}$ & -123.50 \\
\hline \multicolumn{10}{|c|}{ Remaining biomass } \\
\hline FPI-I & Gaussian & 3.03 & 10.43 & 14.17 & 77 & Strong & 0.92 & 4.99 & 35.53 \\
\hline FPI-II & Exponential & 0.00 & 27.92 & 31.49 & 100 & Strong & 0.97 & 4.27 & 32.58 \\
\hline NF-I & Gaussian & 1.67 & 48.43 & 18.47 & 96 & Strong & 0.97 & 44.90 & 59.67 \\
\hline NF-II & Exponential & 0.00 & 12.24 & 22.22 & 100 & Strong & 0.97 & 1.34 & 22.30 \\
\hline
\end{tabular}


Continuation

\begin{tabular}{lccccccccc}
\hline & & \multicolumn{7}{c}{ Shade $(\%)$} \\
FPI- I & Spherical & 0.00 & 655.00 & 57.00 & 100 & Strong & 0.98 & 14540 & 116.1 \\
FPI-II & Spherical & 0.00 & 393.30 & 64.57 & 100 & Strong & 0.99 & 613 & 97.89 \\
NF-I & Spherical & 20.10 & 103.80 & 46.20 & 84 & Strong & 0.96 & 229 & 83.20 \\
NF-II & Spherical & 0.00 & 1.00 & 57.11 & 100 & Strong & 0.98 & 0.01 & -40.03 \\
\hline
\end{tabular}

${ }^{(1)} \mathrm{C}_{0}$ : nugget effect; ${ }^{(2)} \mathrm{C}_{1}$ : level effect; ${ }^{(3)} \mathrm{A}$ : range effect; ${ }^{(4)} \mathrm{DSD}$ : degree of spatial dependence; ${ }^{(5)} \mathrm{SSR}$ : sum of squared residuals, ${ }^{(6)}$ AIC: Akaike criterion, ${ }^{(*)} \mathrm{R}^{2}$ : determination coefficient.

The degree of spatial dependence (DSD) values were strong for all of the sites and variables studied (Table 3). This result indicates that the component related to random variation $\left(\mathrm{C}_{0}\right)$ was much lower than the component related to structured variation $\left(\mathrm{C}_{1}\right)$. Therefore, it is expected that the phenomenon described by models fitted to semivariograms can be represented by the interpolation via ordinary kriging with higher precision (VIEIRA et al., 2010), consequently generating contour maps that allow for identifying different sites or zones of plant litter deposition and nutrient accumulation. The identification of these zones may aid in generating management techniques to improve the benefits of FPI systems implemented in thinned forests.

According to Vieira et al. (2010), the range of spatial dependence indicates the maximum distance where the sampling points are correlated among themselves. Thus, the higher the range, the higher the homogeneity among the samples will be. Additionally, this attribute may indicate the interval between management units. The highest ranges observed for the annual deposition of plant litter occurred at the FPI-I and FPI-II sites. Regarding mineral nutrients present in the plant litter, the FPI-I site had ranges very close to those found at NF-II. Thus, the ranges varied from 14.17 to $117.20 \mathrm{~m}$ (Table 3). Worsham et al. (2010) showed that the range varied from 34.90 to $98.80 \mathrm{~m}$ for carbon and $\mathrm{N}$ levels in plant litter. Therefore, the sampling grid used was sufficient to express the spatial variability of the investigated variables.

Thus, the results allowed for characterizing the phenomena at the investigated sites. Based on the models obtained in the semivariograms fitted for each studied environment, the values of the variables are estimated for the non-sampled sites using ordinary kriging interpolation. Finally, with the generated values, it was possible to construct contour maps (Figure 2) that express the spatial variability of these variables according to soil occupation.

Plant litter production maps allow for identifying different deposition zones (Figure 2). At the FPI-I site, two locations where deposition of approximately 500 and $800 \mathrm{~g} \mathrm{~m}^{-2}$ was concentrated and others in which there was no deposition can be clearly observed. At the FPI-II site, the amplitude $\left(600 \mathrm{~g} \mathrm{~m}^{-2}\right)$ among the sites with higher and lower deposition was slightly decreased compared to FPI-I, but it was still possible to identify two spots with values of 500 and $700 \mathrm{~g} \mathrm{~m}^{-2}$ and locations with low values $\left(100 \mathrm{~g} \mathrm{~m}^{-2}\right)$. The site occupied by NF-I had a more regular spatial distribution with locations of minimum and maximum plant litter production of $300 \mathrm{~g} \mathrm{~m}^{-2}$ and $600 \mathrm{~g} \mathrm{~m}^{-2}$, respectively. Finally, the amplitude of deposition was considerably decreased at NF-II $\left(300 \mathrm{~g} \mathrm{~m}^{-2}\right)$, but spots with higher (700 g $\left.\mathrm{m}^{-2}\right)$ and lower $\left(400 \mathrm{~g} \mathrm{~m}^{-2}\right)$ plant litter concentration were still identified.

The same spatial distribution patterns recorded for plant litter deposition were observed for the mineral nutrients $(\mathrm{N}, \mathrm{P}, \mathrm{K}, \mathrm{Ca}$, and $\mathrm{Mg}$ ) returned by the biomass at the FPI-I and FPI-II sites. The NF-I and NF-II sites exhibited spots of accumulated $\mathrm{K}$ at different locations than those found for plant litter deposition (Figure 2). In this case, there were no plausible elements that can explain this difference 
regarding the phenomena associated with $\mathrm{K}$ availability, unless potentially runoff from the tree crowns and/or even from plant litter deposited on the collectors could have altered these spatial patterns. According to Luizão (2007), runoff from tree crowns as a result of strong and frequent rainfall in the tropics produces important input flow of $\mathrm{Mg}$ and particularly $\mathrm{K}$; the latter is highly water-soluble.

The final biomass of the plant litter incubated in the nylon bags exhibited higher variations within the NF-I site with recording zone values equal to
$85 \%$ and others with $45 \%$ (Figure 2). The spatial distribution was more homogeneous at the other sites although there were points of lower and higher remaining biomass. The decomposition process and mass loss in the nylon bags are particularly affected by soil fauna, which will dictate the pace of plant litter nutrient return to the soil (Luizão, 2007). Therefore, these zones could exhibit characteristics that favor or inhibit the action of the soil organisms that will be reflected in the productive responses of the grass grown at FPI-I and FPI-II because of variations in mineral nutrient availability.

Figure 2. Contour maps of the spatial distribution of plant litter annual production, mineral nutrient return, biomass remaining after 12 months of decomposition, and shade level in forest-pasture integration systems of Marandu grass with 50 (FPI-I) and 70\% (FPI-II) shade in a thinned forest with 80\% shade (NF-I) and an intact native forest (NF-II).

Continue ...

FPI-I

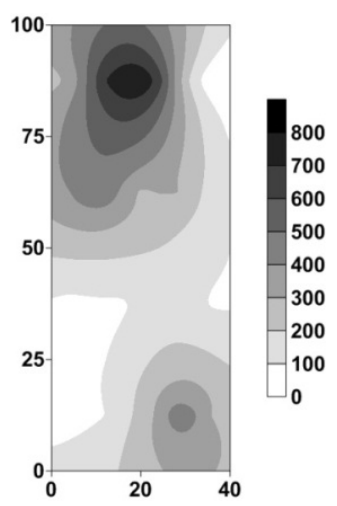

FPI-I

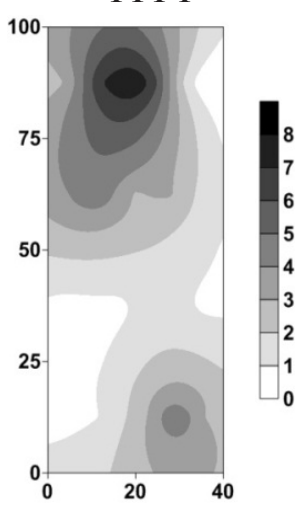

Total deposited plant litter $\left(\mathrm{g} \mathrm{m}^{-2}\right)$

FPI-II

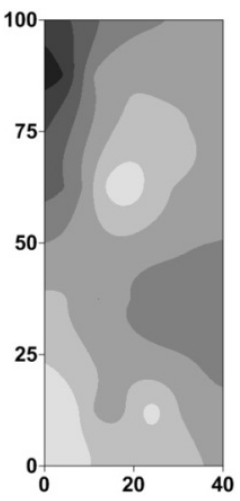

FPI-II

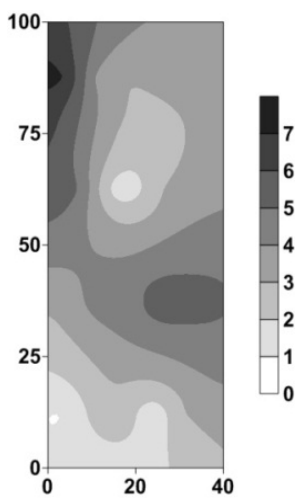

NF-I

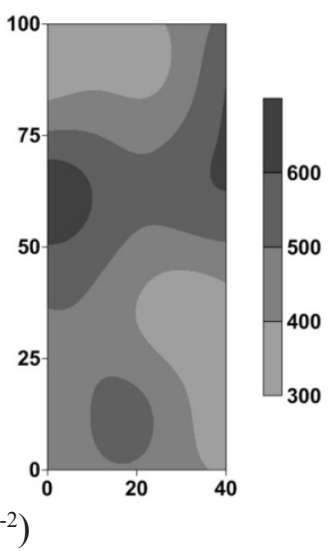

NF-I

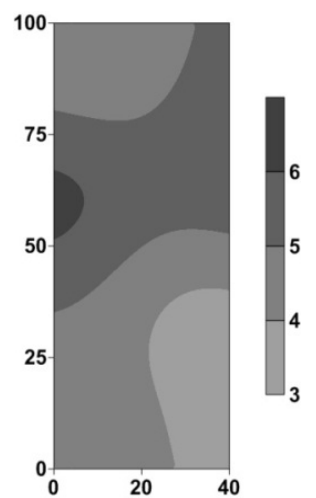

NF-II

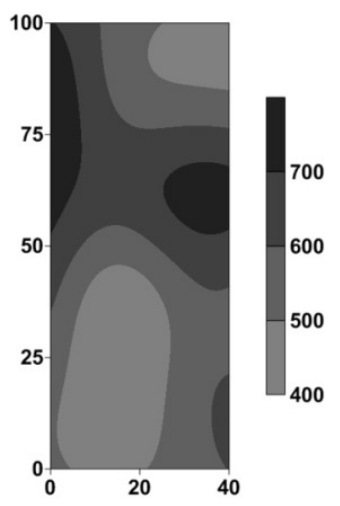

NF-II

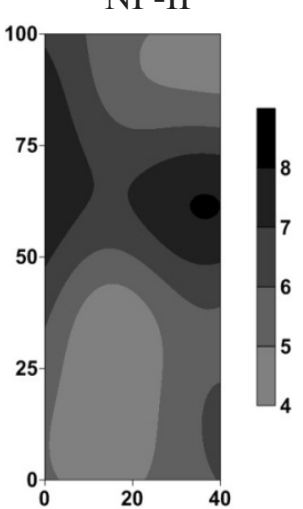




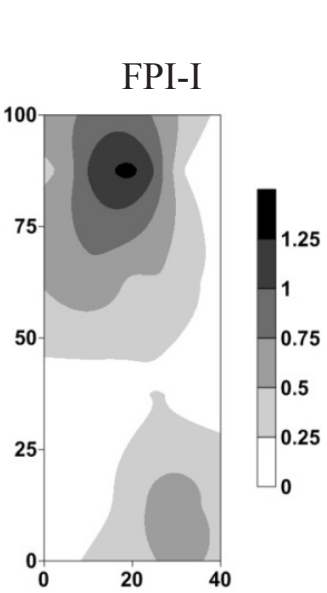

FPI-I

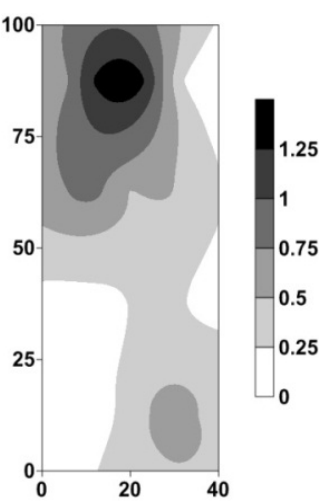

FPI-I

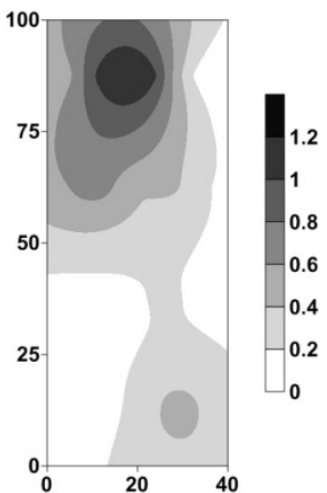

$\mathrm{P}\left(\mathrm{g} \mathrm{m}^{-2}\right)$
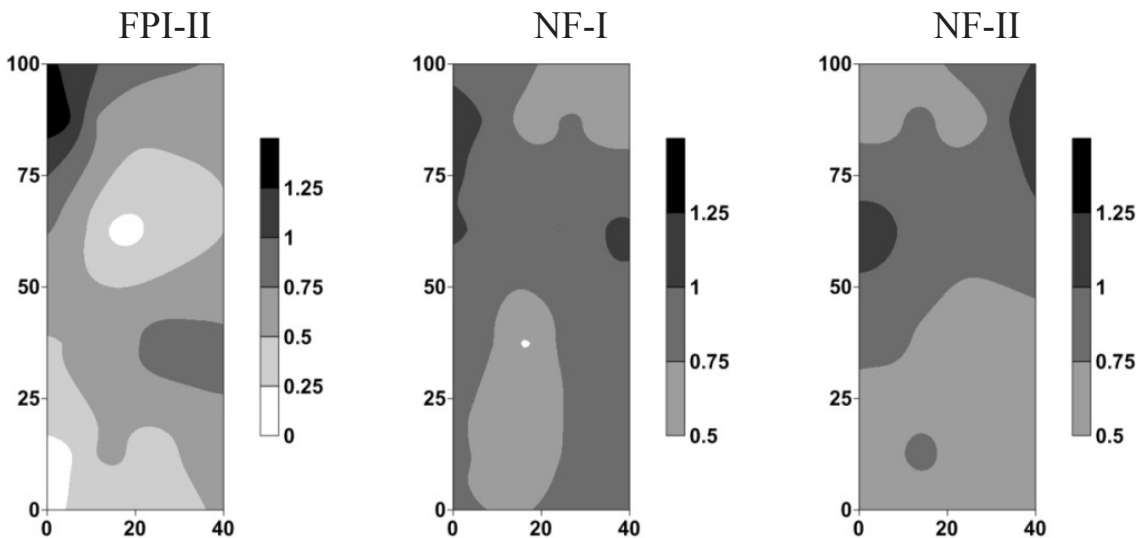

$\mathrm{K}\left(\mathrm{g} \mathrm{m}^{-2}\right)$
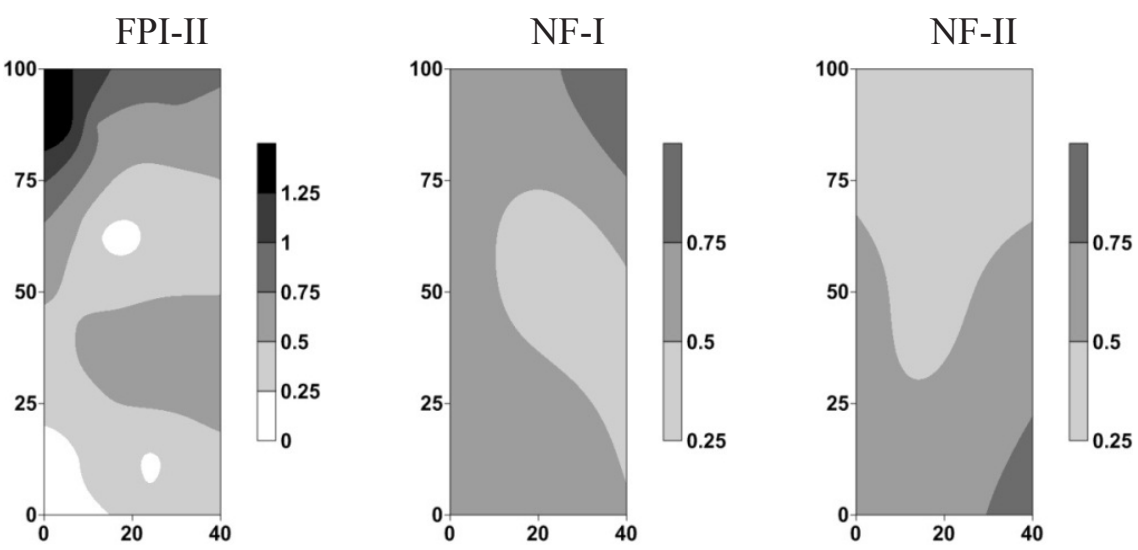

$\mathrm{Ca}\left(\mathrm{g} \mathrm{m}^{-2}\right)$
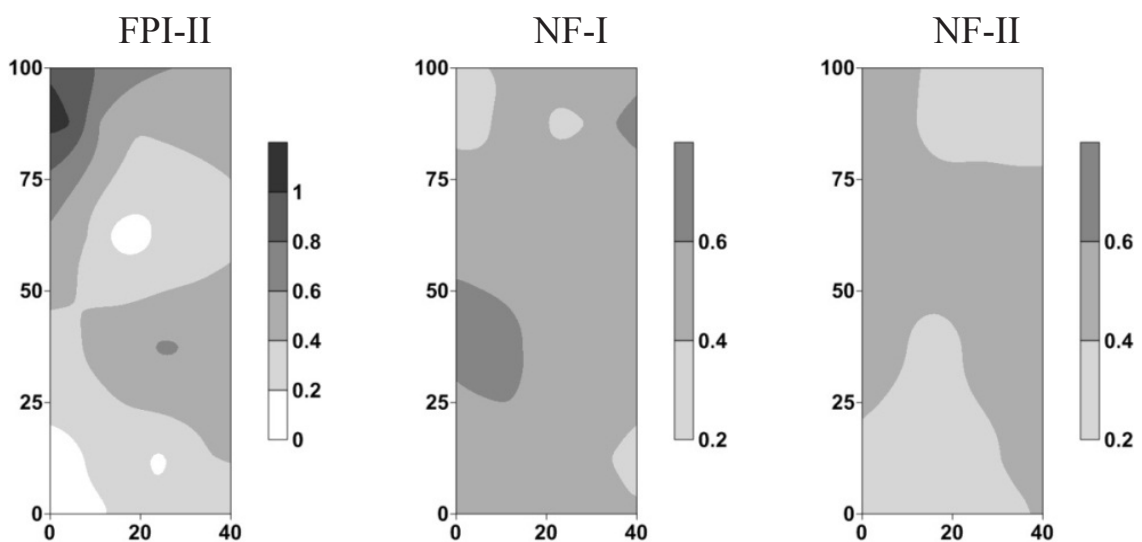


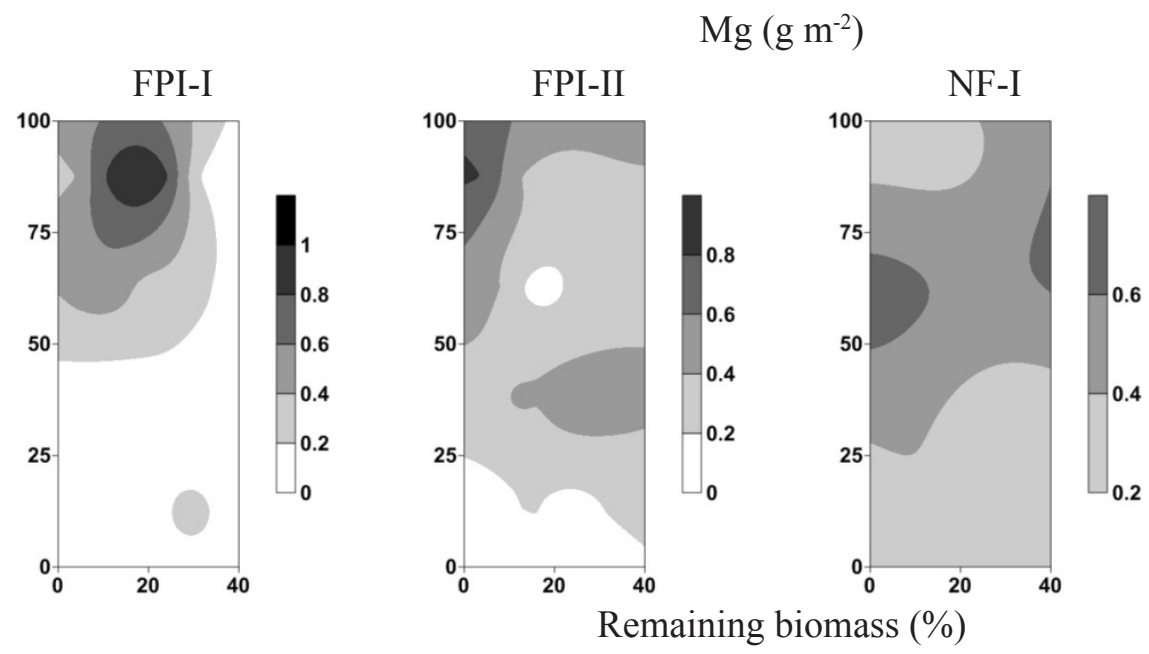

... Continuation
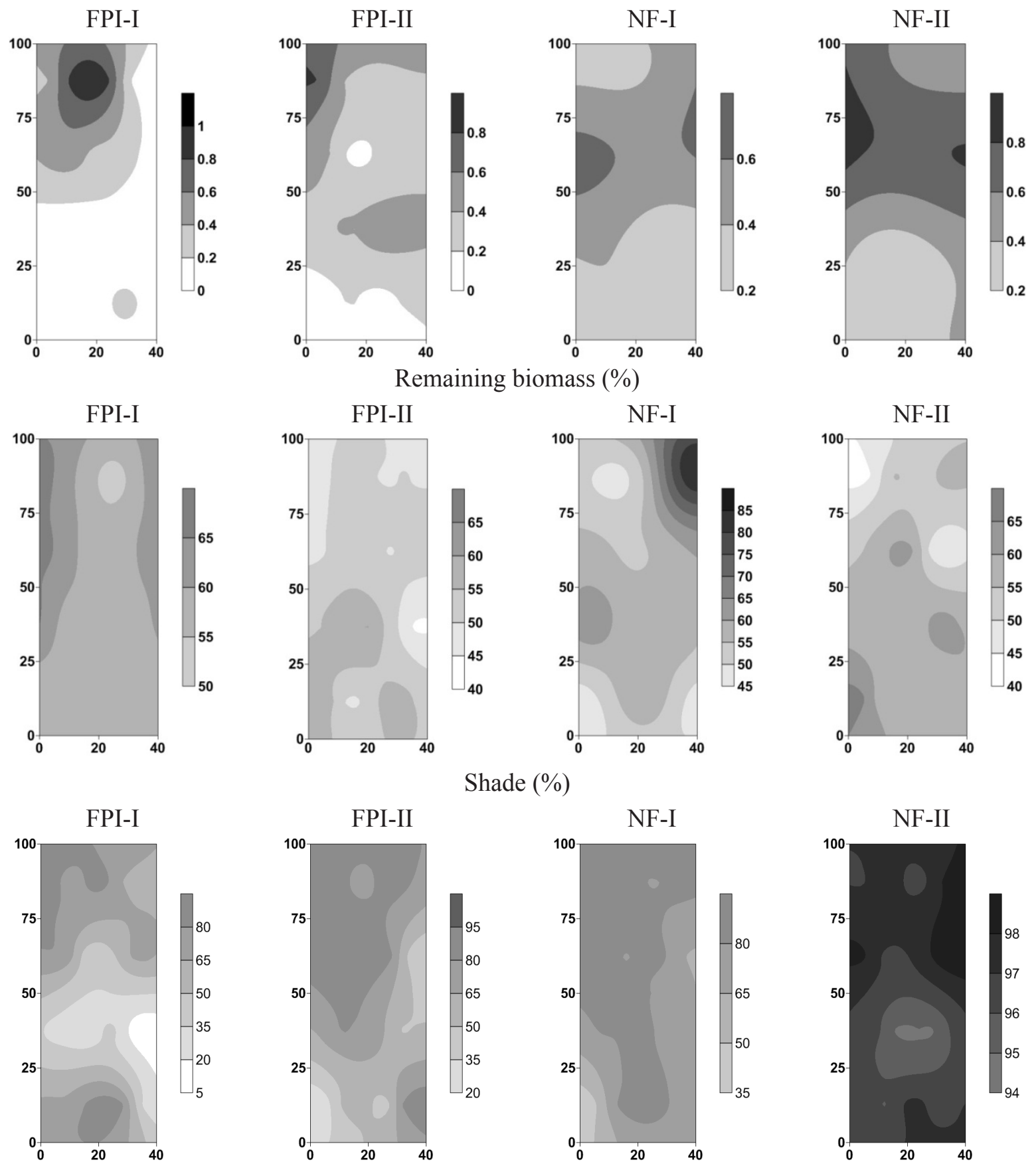

The grasses' responses to the spatial distribution of the shade may also lead to different results because the effects of tree canopy projection can generate locations with distinct shade levels in the same site. According to Paciullo et al. (2011), the region between 7 and $10 \mathrm{~m}$ from the

hedgerow exhibits greater benefits to the pasture characteristics with moderate shade. Thus, there is a presence of different locations with distinct responses of the observed and mapped variables using geostatistical procedures, which reinforces the point that using mean values does not allow for 
adequately observing the phenomena that occur at the site (Figure 2).

Based on the values that were generated by ordinary kriging interpolation, principal component analysis (PCA) was performed to identify and classify the variability in the attributes studied at each site. After PCA, two components were extracted that exhibited eigenvalues higher than one and cumulatively explained $91.05,89.76$, 71.96 , and $82.77 \%$ of the total variability in the data at the FPI-I, FPI-II, NF-I, and NF-II sites, respectively (Table 4). Thus, this result indicates that out of the eight original variables, two components represented the original set having $8.95,10.24,28.04$, and $17.23 \%$ lost explanation at the FPI-I, FPI-II, NF-I, and NF-II sites, respectively (Table 4).

Table 4. Principal component analysis summary.

\begin{tabular}{|c|c|c|c|c|c|c|c|c|}
\hline \multirow{4}{*}{ Variance component } & \multicolumn{8}{|c|}{ Site } \\
\hline & \multicolumn{2}{|c|}{ FPI-I $^{1}$} & \multicolumn{2}{|c|}{ FPI-II $^{2}$} & \multicolumn{2}{|c|}{ NF-I ${ }^{3}$} & \multicolumn{2}{|c|}{ NF-II ${ }^{4}$} \\
\hline & \multicolumn{8}{|c|}{ Principal component } \\
\hline & $1^{\mathrm{st}}$ & $2^{\text {nd }}$ & $1^{\text {st }}$ & $2^{\text {nd }}$ & $1^{\text {st }}$ & $2^{\text {nd }}$ & $1^{\text {st }}$ & $2^{\text {nd }}$ \\
\hline Eigenvalue & 6.23 & 1.05 & 6.38 & 0.80 & 4.33 & 1.42 & 5.10 & 1.51 \\
\hline Variance $(\%)$ & 77.93 & 13.11 & 79.73 & 10.03 & 54.16 & 17.80 & 63.83 & 18.94 \\
\hline Cumulative variance & 77.93 & 91.05 & 79.73 & 89.76 & 54.16 & 71.96 & 63.83 & 82.77 \\
\hline
\end{tabular}

(1) FPI-I: Forest-pasture integration system of Marandu grass with 50\% shade; (2) FPI-II: Forest-pasture integration system of Marandu grass with $70 \%$ shade; ${ }^{(3)} \mathrm{NF}-\mathrm{I}$ : Thinned forest with $80 \%$ shade; ${ }^{(4)} \mathrm{NF}-\mathrm{II}$ : Intact native forest.

The first principal component represented $77.93,79.73,54.16$, and $63.83 \%$ of the total variability of the data when analyzed separately at the FPI-I, FPI-II, NF-I, and NF-II sites, respectively (Table 4). At the FPI-I site, the plant litter deposition and all of the mineral nutrient variables exhibited a high positive correlation with this component (Table 5). Therefore, this new variable represented the ability to return plant biomass and nutrients to the soil at this site. At FPIII, in addition to these variables, the final biomass was also highly correlated, which indicates that the new variable was related to the ability to return plant litter and mineral nutrients and to decompose the deposited material. At the forested sites, the deposited plant litter, $\mathrm{N}, \mathrm{P}$, and $\mathrm{Mg}$ were highly correlated with the first component (Table 5). It is noteworthy that NF-II also includes $\mathrm{Ca}$ in this situation. These results indicate that only some nutrients and plant litter will contribute to the dissimilarity of the management zones compared to the studied phenomena. It is noteworthy that the first principal component is always the most important component (GUEDES et al., 2006), and its variables have a higher weight in the classification. 
Table 5. Correlation between the original variables and principle components of annual plant litter production, mineral nutrient return, biomass remaining after 12 months of decomposition, and shade level in forest-pasture integration systems of Marandu grass with 50 (FPI-I) and 70\% (FPI-II) shade in a thinned forest with $80 \%$ ICD (NF-I) and an intact native forest (NF-II).

\begin{tabular}{|c|c|c|c|c|c|c|c|c|}
\hline \multirow{4}{*}{ Variable } & \multicolumn{8}{|c|}{ Site } \\
\hline & \multicolumn{2}{|c|}{ FPI-I } & \multicolumn{2}{|c|}{ FPI-II } & \multicolumn{2}{|c|}{ NF-I } & \multicolumn{2}{|c|}{ NF-II } \\
\hline & \multicolumn{8}{|c|}{ Principal component } \\
\hline & $1^{\text {st }}$ & $2^{\text {nd }}$ & $1^{\text {st }}$ & $2^{\text {nd }}$ & $1^{\mathrm{st}}$ & $2^{\text {nd }}$ & $1^{\text {st }}$ & $2^{\text {nd }}$ \\
\hline Plant litter & 0.99 & 0.40 & 0.97 & -0.17 & 0.89 & -0.22 & 0.97 & 0.16 \\
\hline $\mathrm{N}$ & 0.99 & -0.09 & 0.92 & -0.21 & 0.92 & -0.30 & 0.97 & 0.15 \\
\hline $\mathrm{P}$ & 0.99 & -0.10 & 0.96 & -0.20 & 0.97 & -0.03 & 0.87 & 0.42 \\
\hline K & 0.99 & -0.05 & 0.96 & 0.01 & 0.25 & 0.84 & -0.28 & 0.85 \\
\hline $\mathrm{Ca}$ & 0.99 & -0.02 & 0.98 & -0.11 & 0.55 & 0.31 & 0.84 & 0.41 \\
\hline $\mathrm{Mg}$ & 0.97 & 0.04 & 0.97 & -0.05 & 0.93 & -0.33 & 0.92 & -0.25 \\
\hline Remaining biomass & 0.11 & 0.94 & -0.70 & -0.42 & 0.62 & 0.58 & -0.65 & 0.38 \\
\hline Shade & 0.60 & 0.30 & 0.58 & 0.71 & 0.37 & 0.18 & 0.63 & -0.44 \\
\hline
\end{tabular}

Numbers in bold highlight the variables that are highly correlated $(>0.70)$ with the principle components.

The second principal component only represented 13.11, 10.03, 17.80, and $18.94 \%$ of the total variation in the data of the FPI-I, FPI-II, NF-I, and NF-II sites, respectively (Table 4). At the FPI-I site, this component had a higher correlation with the quantity of biomass remaining after one year of plant litter incubation (Table 5). This new variable clustered the sites with similarity and final biomass. At the FPI-II site, the shade level of the tree canopy contributed in the sense of classifying the sites. Finally, at the NF-I and NF-II sites, this clustering of similar points was a result of $\mathrm{K}$ return via plant litter (Table 5).

Based on these new variables created by the PCA, management zones were defined that can exhibit different responses to the productive system as a function of the variables investigated. For this purpose, the non-hierarchical fuzzy k-mean clustering technique was used, which is an iterative method that has a greater capacity to analyze larger datasets (MINGOTI, 2005). To define the adequate number of classes, the fuzzy performance index (FPI) value and modified partition entropy (MPE) were determined as a function of the number of clustering classes of the data at each site (Figure $4 a, 4 b, 4 c, 4 d)$. Based on the results of the FPI and MPE indices exhibited in Figure 3, the optimal number of soil management classes would be 3, 5, 4, and 3 for the FPI-I, FPI-II, NF-I, and NF-II sites, respectively. 
Figure 3. Circle of the correlations and ordination diagram of the plane formed by principle components 1 and 2 at the sites of forest-pasture integration systems of Marandu grass with 50 (FPI-I) and 70\% (FPI-II) shade in a thinned forest with $80 \%$ shade (NF-I) and an intact native forest (NF-II).

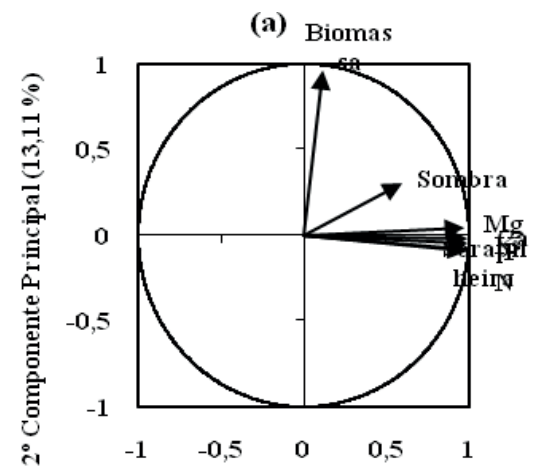

(b)

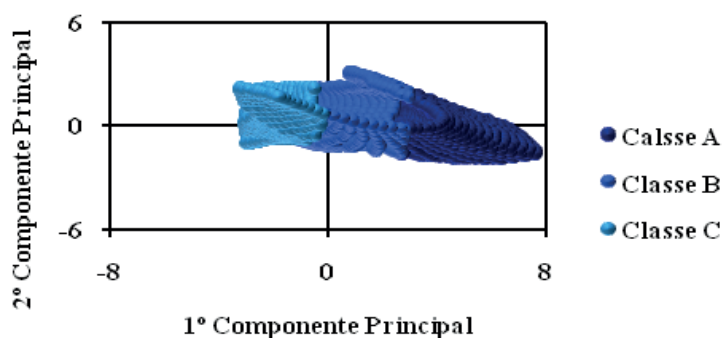

$1^{\circ}$ Componente Principal - (77,93\%

(c)

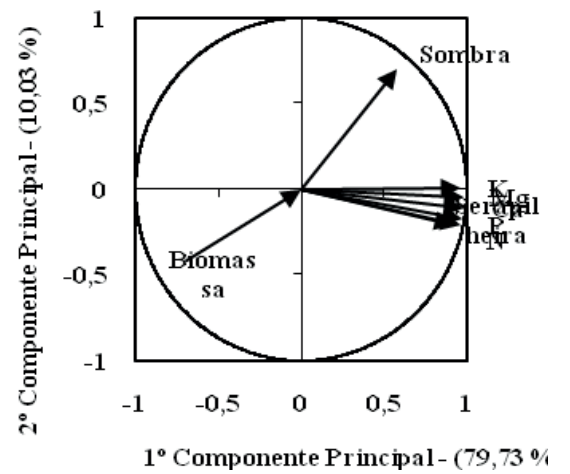

(d)

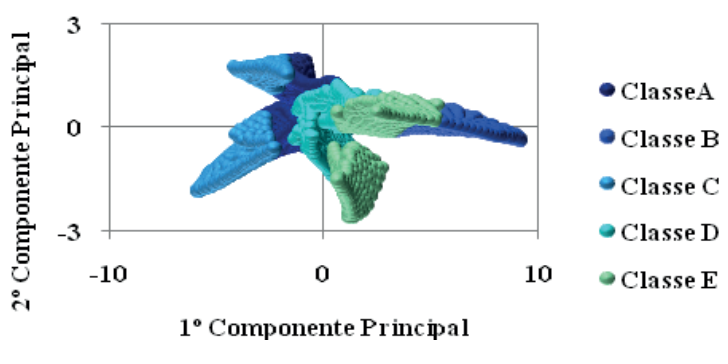

(e)

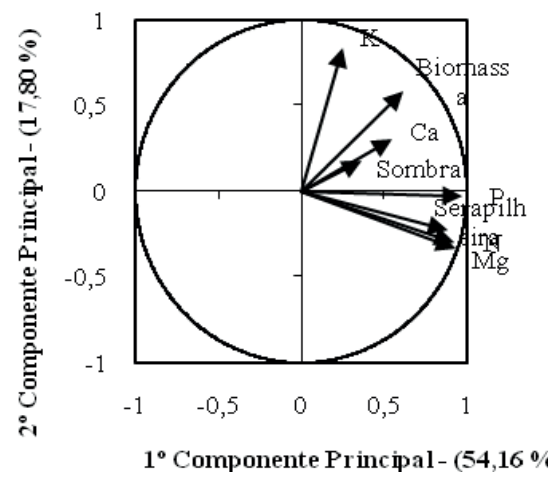

(f)

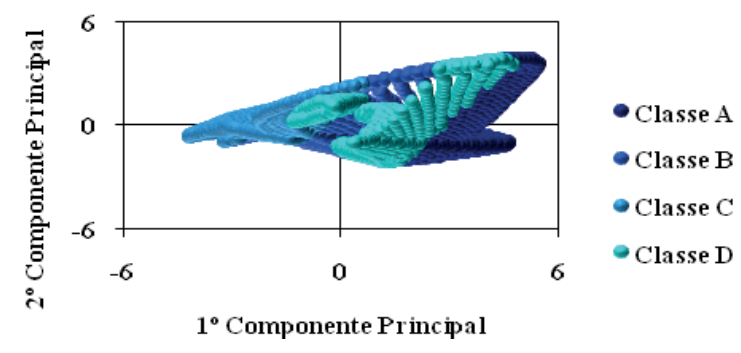

(g)

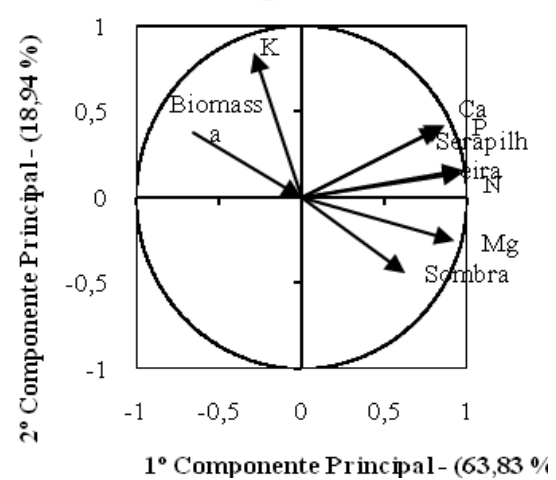

(h)

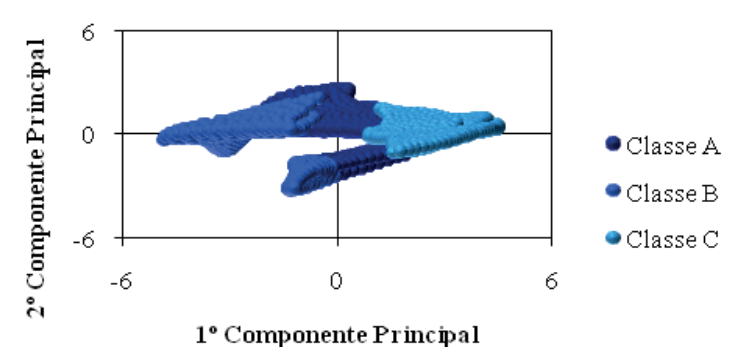

Semina: Ciências Agrárias, Londrina, v. 36, n. 6, suplemento 2, p. 4377-4400, 2015 
Figure 4. FPI and MPE index values as a function of the numbers of classes at the sites of forest-pasture integration systems of Marandu grass with 50 (FPI-I) and 70\% (FPI-II) shade in a thinned forest with $80 \%$ shade (NF-I) and an intact native forest (NF-II).

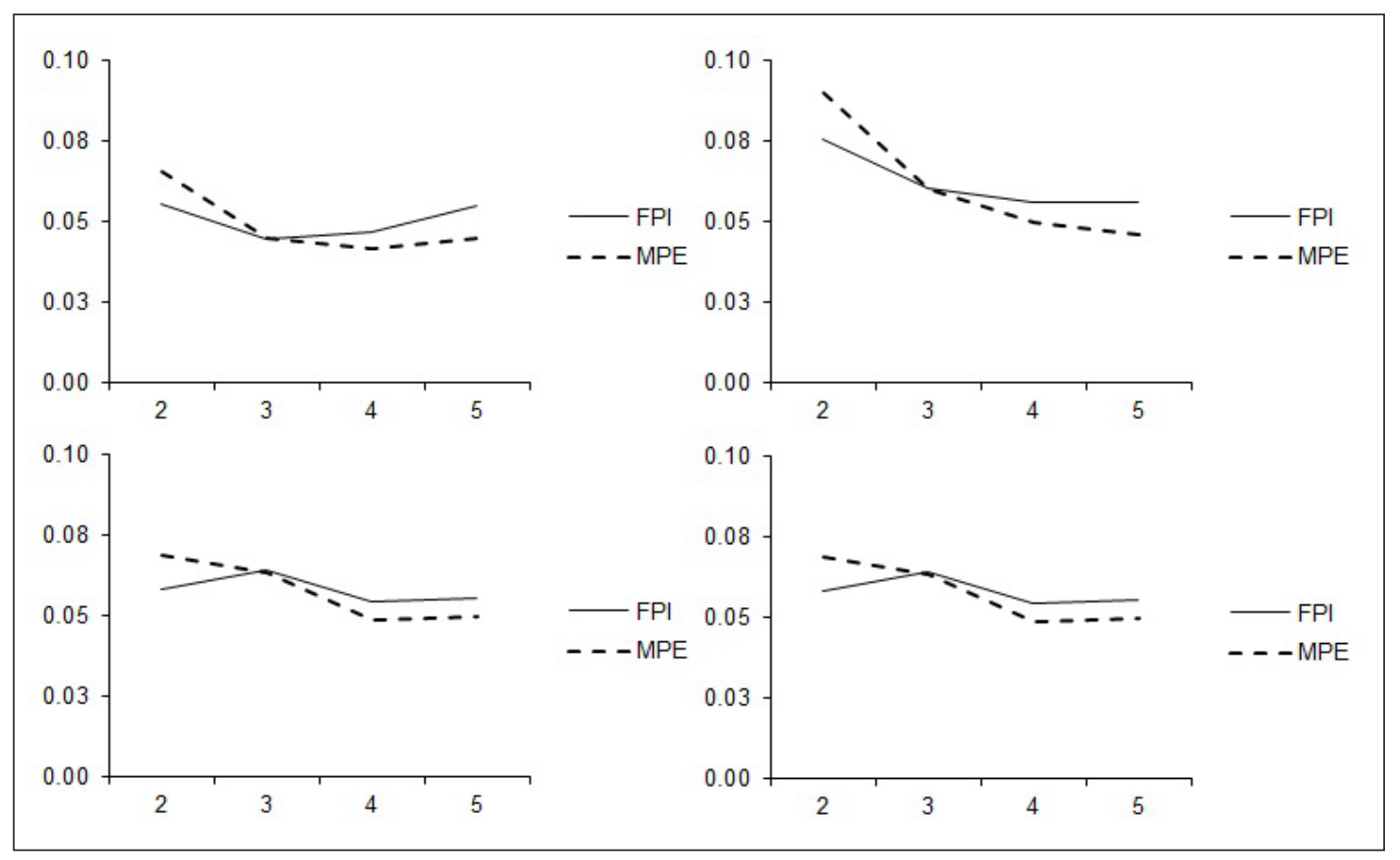

After the ideal number of classes was defined, interpolation of the data was performed according to the participation of each individual $i$ in one of the classes $k$ using the natural neighbor interpolation method (Figure 5). In analyzing the maps, it is noteworthy that the classes generated by fuzzy k-mean logic were mainly grouped because of plant litter deposition and shade level (Figure 2). The
NF-I site with the highest plant litter deposition only coincided with the second highest shade level at the site. This situation may have occurred from the use of a photometer to determine shade at the sites because the measurements taken by this equipment are sensitive to small variations in luminosity at the time of the reading (SUGANUMA et al., 2008). 
Figure 5. Contour maps of the management classes at the sites of forest-pasture integration systems of Marandu grass with 50 (FPI-I) and 70\% (FPI-II) shade in a thinned forest with 80\% shade (NF-I) and an intact native forest (NF-II).
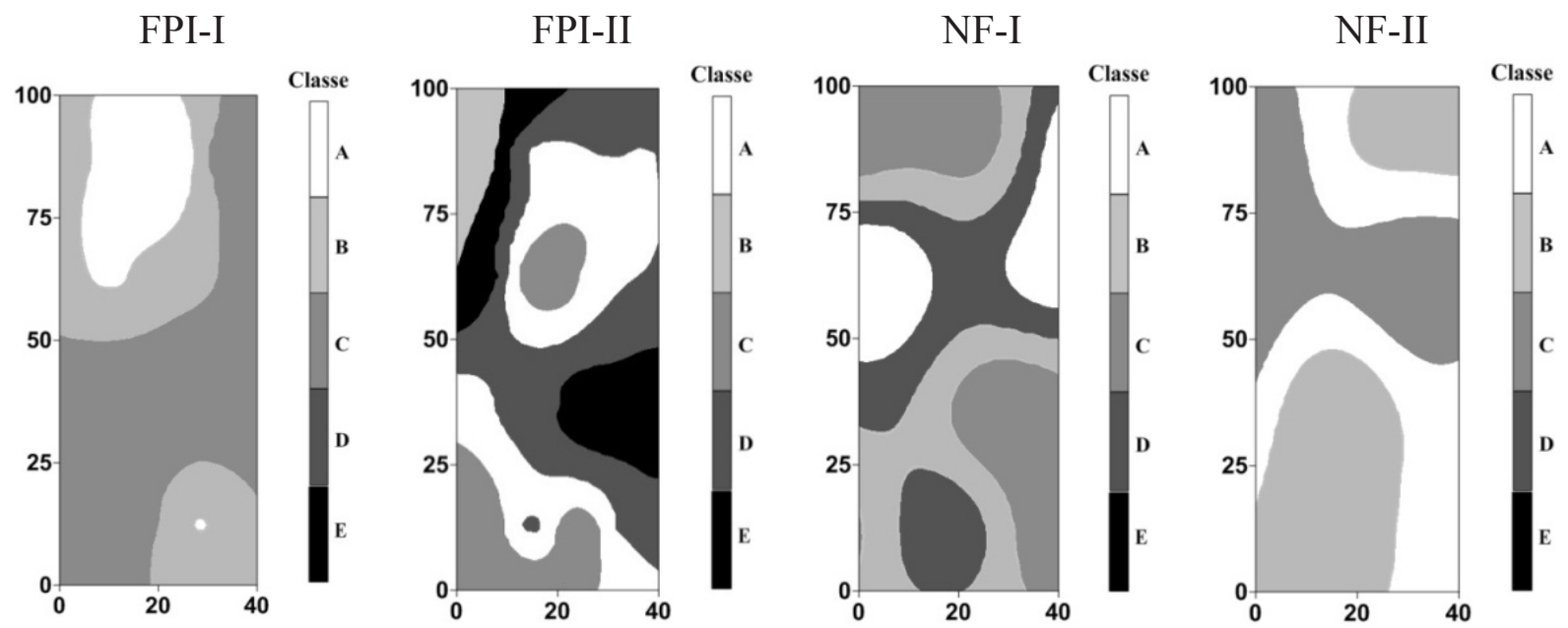

Finally, analysis of variance (ANOVA) was performed to test the existence of differences between the management classes created by the fuzzy k-mean algorithm. Thus, the division generated by the algorithm can be validated, similar to a principal component analysis. Table 6 shows the results of the ANOVA among the classes generated. Nutrient production and return remained restricted at the sites with a higher

shade level. These conditions can lead to the formation of locations (spots) where the grass will be sized differently from the others, which results in different points of regrowth (SALTON, CARVALHO, 2007). This regrowth may alter the behavioral patterns of the animals and their interaction with the vegetation in a heterogeneous environment (LACA, 2009). 


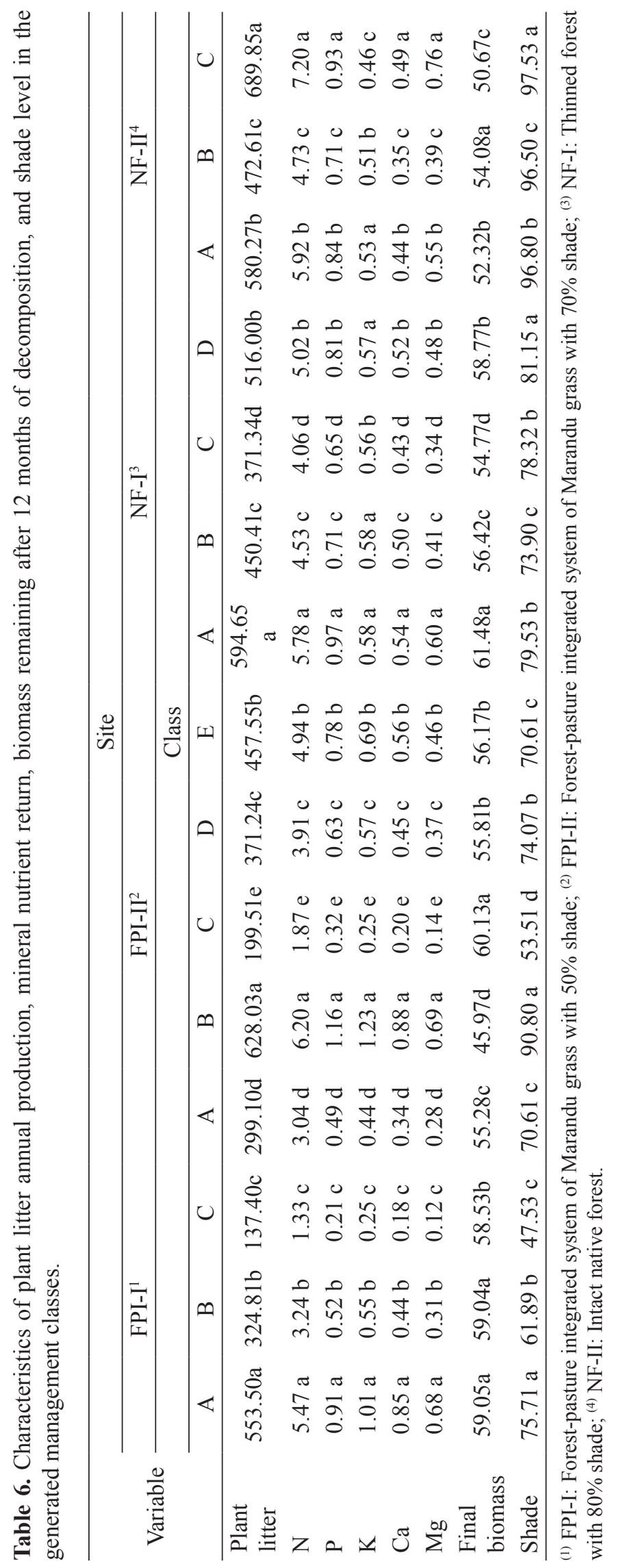




\section{Conclusions}

It has been shown that it is possible to quantify, describe, and define plant litter production and nutrient accumulation zones in different forestpasture integration systems and forest strata of the Cerrado-Amazon transition on orthic Quartzarenic Neosol using geostatistical analyses, principal components, and non-hierarchical fuzzy k-mean clustering logic procedures.

\section{Acknowledgements}

To the National Council for Scientific and Technological Development (Conselho Nacional de Desenvolvimento Científico e Tecnológico $\mathrm{CNPq}$ ) and the Brazilian Federal Agency for the Support and Evaluation of Graduate Education (Coordenação de Aperfeiçoamento de Pessoal de Nível Superior - CAPES) for awarding financial support and scholarships.

\section{References}

CAVAlCANTE, E, G. S.; ALVES, M. C.; SOUZA, Z. M.; PEREIRA, G. T. Variabilidade espacial de atributos físicos do solo sob diferentes usos e manejos. Revista Brasileira de Engenharia Agrícola e Ambiental, Campina Grande, v. 15, n. 3, p. 237-243, 2011.

CERRI, C. E. P.; CERRI, C. C.; PAUSTIAN, K.; BERNOUX, M.; MELLILO, J. M. Combining soil C and $\mathrm{N}$ spatial variability and modeling approaches for measuring and monitoring soil carbon sequestration. Environmental Management, New York, v. 33, p. S274-S288, 2004. Supplement 1.

CIANCIARUSO, M. V.; PIRES, J. S. R.; DELITTI, W. B. C.; SILVA, E. F. L. P. Produção de serapilheira e decomposição do material foliar em um cerradão da Estação Ecológica de Jataí, município de Luiz Antônio, SO, Brasil. Acta Botanica Basilica, Belo Horizonte, v. 20 n. 1, p. 49-59, 2006.

DIAS-FILHO, M. B.; FERREIRA, J. N. Barreiras para adoção de sistemas silvipastoris. In: SIMPÓSIO DE FORRAGICULTURA E PASTAGEM, 6., 2007, Lavras. Anais... Lavras: UFLA, 2007. p. 347-365.
EMPRESA BRASILEIRA DE PESQUISA AGROPECUÁRIA - EMBRAPA. Manual de laboratórios: solo, água, nutrição vegetal, nutrição animal e alimentos. São Carlos: EMBRAPA Pecuária Sudeste, 2005. 334 p.

Sistema brasileiro de classificação de solos. Brasília: EMBRAPA Produção de Informação, 2006. $306 \mathrm{p}$.

FREIRE, J. L.; DUBEUX JÚNIOR, J. C. B.; LI, M. A.; FERREIRA, R. L. C.; SANTOS, M. V. F.; FREITAS, E. V. Decomposição da serrapilheira em bosque de sabiá na Zona da Mata de Pernambuco. Revista Brasileira de Zootecnia, Viçosa, MG, v. 39, n. 8, p. 1659-1665, 2010.

GOLDEN SOFTWARE. Surfer for Windows version 8.0. Colorado: Golden, 2002.

GUEDES, M. C.; ANDRADE, C. A.; POGGIANI, F.; MATTIAZZO, M. E. Propriedades químicas do solo e nutrição do eucalipto em função da aplicação de lodo de esgoto. Revista Brasileira de Ciência do Solo, Viçosa, MG, v. 30, n. 2, p. 267-280, 2006.

ISAAKS, E. H.; SRIVASTAVA, R. M. An introduction to applied geoestatistics. New York: Oxford University, 1989. $561 \mathrm{p}$.

KRAVCHENKO, A. N.; ROBERTSON, G. P.; SNAP, S. S.; SMUCKER, A. J. M. Using information about spatial variability to improve estimates of total soil carbon. Agronomy Journal, Madison, v. 98, n. 3, p. 823-829, 2006.

LACA, E. A. Precision livestock production: tools and concepts. Revista Brasileira de Zootecnia, Viçosa, MG, v. 38, p. 123-132, 2009. Suplemento Especial.

LEÃO, M. G. A.; MARQUES JÚNIOR, J.; SOUZA, Z. M.; SIQUEIRA, D. S.; PEREIRA, G. T. O relevo na interpretação da variabilidade espacial dos teores de nutrientes em folhas de citros. Revista Brasileira de Engenharia Agricola e Ambiental, Campina Grande, v. 14, n. 11, p. 1152-1159, 2010.

LUIZÃO, F. J. Ciclos de nutrientes na Amazônia: respostas à mudanças ambientais e climáticas. Ciência e Cultura, São Paulo, v. 59, n. 3, p. 31-36, 2007.

LUIZÃO, F. J.; SCHUBART, H. O. R. Litter production and decomposition in a terra-firme forest of Central Amazonia. Experientia, Berlin, v. 43, n. 3, p. 259-265, 1987.

MARDIA, K. V.; KENT, J. T.; BIBBY, J. M. Multivariate analysis. London: Academic, 1979. $521 \mathrm{p}$.

MATHERON, G. Principles of geostatistics. Economic Geology, Littleton, v. 58, n. 8, p. 1246-1266, 1963. 
MENEZES, R. S. C.; SALCEDO, I. H.; ELLIOTT, E. T. Microclimate and nutrint dynamic in a silvopastoral system of semiarid northeastern Brazil. Agroforetry Systems, Amsterdam, v. 56, n. 27, p. 27-38, 2002.

MINASNY, B.; MCBRATNEY, A. B. FuzMe version 3.0. Australian Center of Precision Agriculture, The University of Sidney. Sydney: The University of Sidney, 2002. 26 p.

MINASNY, B.; MCBRATNEY, A. B.; WHELAN, B. M. VESPER version 1.62. Australian Centre for Precision Agriculture, McMillan Building A05. The University of Sydney, NSW. Sydney: The University of Sidney, 2006. Available at: <http://www.usyd.edu.au/su/agric/acpa>. Accessed at: 11. Dez. 2012.

MINGOTI, S. A. Análise de dados através de métodos de estatística multivariada: uma abordagem aplicada. Belo Horizonte: Editora UFMG, 2005. 297 p.

MOLIN, J. P.; CASTRO, C. N. establishing management zones using soil electrical conductivity and other soil properties by the fuzzy clustering technique. Scientia Agricola, Piracicaba, v. 65, n. 6, p. 5 67-573, 2008.

NEVES, C. M. N.; SILVA, M. L. N.; CURI, N.; MACEDO, R. L. G.; MOREIRA, F. M. de S.; D’ANDRÉA, A. F. Indicadores biológicos da qualidade do solo em sistema agrossilvipastoril no noroeste do Estado de Minas Gerais. Ciência e Agrotecnologia, Lavras, v. 33, n. 1, p. 105-112, 2009.

NOGUEIRA, M. C. S. Experimentação agronômica $I$. Piracicaba: Universidade de São Paulo, 2007. 463 p.

OLIVEIRA, T. K.; MACEDO, R. L. G.; SANTOS, I. P. A.; HIGASHIKAWA, E. M.; VENTURIM, N. Produtividade de Brachiaria brizantha (Hochst. ex A. Rich.) Stapf cv. Marandusob diferentes arranjos estruturais de sistema agrossilvipastoril com eucalipto. Ciência Agrotecnologica, Lavras, v. 31, n. 3, p. 748-757, 2007.

PACIULLO, D. S. C.; CAMPOS, N. R.; GOMIDE, C. A. M.; CASTRO, C. R. T.; TAVELA, R. C.; ROSSIELLO, R. O. P. Crescimento de capim-braquiária influenciado pelo grau de sombreamento e pela estação do ano. Pesquisa Agropecuária Brasileira, Brasília, v. 43, n. 7, p. 917-923, 2008.

PACIULlO, D. S. C.; GOMIDE, C. A. M.; CASTRO, C. R. T.; FERNANDES, P. B.; MÜllER, M. D.; PIRES, M. F. A.; FERNANDES, E. N.; XAVIER, D. F. Características produtivas e nutricionais do pasto em sistema agrossilvipastoril, conforme a distância das árvores. Pesquisa Agropecuária Brasileira, Brasília, v. 46, n. 10, p. 1176-1183, 2011.
REIS, G. L.; LANA, A. M. Q.; MAURÍCIO, R. M.; LANA, R. M. Q.; MACHADO, R. M.; BORGES, I.; QUINZEIRO NETO, T. Influence of trees on soil nutrient pools in a silvopastoral system in the Brazilian Savannah. Plant and Soil, Amsterdam, v. 329, n. 2, p. 185-193, 2009.

ROBERTSON, G. P. GS+: geostatistics for the environmental sciences - GS+ user's guide. Plainwell: Gamma Design Soffware, 2008. 152 p.

RODRIGUES JÚNIOR, F. A.; VIEIRA, L. B.; QUEIROZ, D. M.; SANTOS, N. T. Geração de zonas de manejo para cafeicultura empregando-se sensor SPAD e análise foliar. Revista Brasileira de Engenharia Agrícola e Ambiental, Campina Grande, v. 15, n. 8, p. 778-787, 2011.

RODRIGUES, R. R.; LEITÃO-FILHO, H. F. Matas ciliares: conservação e recuperação. 2. ed. São Paulo: EDUSP, 2004. 320 p.

SALTON, J. C.; CARVALHO, P. C. F. Heterogeneidade da pastage: causas e consequências. Dourados: Embrapa Agropecuária Oeste, 2007. Doc. 91, 41 p.

SANCHES. L.; VALENTINI, C. M. A.; BIUDES, M. S.; NOGUEIRA, J. S. Dinâmica sazonal da produção e decomposição de serrapilheira em floresta tropical de transição. Revista Brasileira de Engenharia Agrícola e Ambiental, Campina Grande, v. 13, n. 2, p. 183-189, 2009.

SANCHES, L.; VALENTINI, C. M. A.; PINTO JÚNIOR, O. B.; NOGUEIRA, J. S.; VOURLITIS, G. L.; BIUDES, M. S.; SILVA, C. J.; BAMBI, P.; LOBO, F. A. Seasonal and interannual litter dynamics of a tropical semideciduous forest of the southern Amazon Basin, Brazil. Journal of Geophisical Research. Washington, v. 113, n. 4, p. 1-9, 2008.

SILVA, C. J.; LOBO, F. A.; BLEICH, M. E.; SANCHES, L. Contribuição de folhas na formação da serrapilheira e no retorno de nutrientes em floresta de transição no norte de Mato-Grosso. Acta Amazônica, Manaus, v. 39, n. 3, p. 591-600, 2009.

SILVA, C. J.; SANCHES, L.; BLEICH, M. E.; LOBO, F. A.; NOGUEIRA, J. S. Produção de serrapilheira no Cerrado e Floresta de transição Amazônia-Cerrado do Centro-Oeste Brasileiro. Acta Amazônica, Manaus, v. 37 , n. 4, p. 543-548, 2007.

SOUSA, L. F.; MAURÍCIO, R. M.; GONÇALVES, L. C.; SALIBA, E. O. S.; MOREIRA, G. R. Produtividade e valor nutritivo da Brachiaria brizantha cv. Marandu em um sistema silvipastoril. Arquivo Brasileiro de Medicina Veterinária e Zootecnia, Belo Horizonte, v. 59, n. 4, p. 1029-1037, 2007. 
SUGANUMA, M. S.; TOREZAN, J. M. D.; CAVALHEIRO, A. L.; VANZELA, A. L. L.; BENATO, T. Comparando metodologias para avaliar a cobertura do dossel e luminosidade no sub-bosque de um reflorestamento e uma floresta madura. Revista Árvore, Viçosa, v. 32, n. 2, p. 377-385, 2008.

VIEIRA, S. R. Geoestatística em estudos de variabilidade espacial do solo. In: NOVAIS, R. F.; ALVAREZ, V. H.; SCHAEFER, C. E. G. R. (Ed.). Tópicos em ciência do solo. Viçosa, MG: Sociedade Brasileira de Ciência do Solo, 2000. v. 1, p. 1-53.

VIEIRA, S. R.; GUEDES FILHO, O.; CHIBA, M. K.; MELLIS, E. V.; DECHEN, S. C. F.; DE MARIA, I. C. Variabilidade espacial dos teores foliares de nutrientes e produtividade da soja em dois anos de cultivo em Latossolo Vermelho. Revista Brasileira de Ciência do Solo, Viçosa, MG, v. 34, n. 5, p. 1503-1514, 2010.

VITOUSEK, P. M.; SANFORD, R. L. Nutrient cycling in moist forest. Annual Review of Ecology and Systematics, Palo Alto, v. 17, n. 4, p. 137-167, 1986.
WARRICK, A. W.; NIELSEN, D. R. Spatial variability of soil physical properties in the field. In: HILLEL, D. (Ed.). Application of soil physics. New York: Academic Press, 1980. p. 319-344.

WORSHAM, L.; MARKEWITZ, D.; NIBBELINK, N. Incorporating spatial dependence into estimates of soil carbon contents under different land covers. Soil Science Society of America, Madison, v. 74, n. 2, p. 635-646, 2010 .

XAVIER, D. F.; CARVALHO, M. M.; ALVIM, M. J.; BOTREL, M. A. Melhoramento da fertilidade do solo em pastagem de Brachiaria decumbens associada com leguminosas arbóreas. Pasturas Tropicales, Cali, v. 25, n. 1, p. 23-26, 2003.

XAVIER, D. F.; LÉDO, F. J. F.; PACIUllO, D. S. C.; PIRES, M. F. A.; BODDEY, R. M. Dinâmica da serapilheira em pastagens de braquiária em sistema silvipastoril e monocultura. Pesquisa Agropecuária Brasileira, Brasília, v. 46, n. 10, p. 1214-1219, 2011. 
